\title{
Makhtesh Ramon Complex Deposit (Southern Israel) - A Window to the Upper Mantle
}

\author{
Lev V. Eppelbaum ${ }^{1}$, Vladimir L. Vaksman ${ }^{2}$ \\ ${ }^{1}$ Dept. of Geosciences, Raymond and Beverly Sackler Faculty of Exact Sciences, \\ Tel Aviv University, Tel Aviv 6997801, Israel \\ ${ }^{2}$ KVGRS Ltd, 30/8 Fayerberg St., Tel Aviv, Israel
}

\begin{abstract}
An integrated analysis of several regional geological and geophysical factors allowed to select the Makhtesh Ramon area (northern Negev, Israel) for sesarching diamondiferous associations. The most important regional factor is the Middle Cretaceous maximum in the development of upper mantle hot spots brightly appearing in this area. Analysis of magnetic (paleomagnetic), self-potential and ionselective data inambigously indicate presence of some bodies possibly having kimberlite (lamproite) origin occurring at small depths $(8-50$ $m$ ) in the western Makhtesh Ramon. Repeated erosion processes in the area caused removing most part of sedimentary associations that significantly simplified the processes of mineral sampling and rock withdrawn for geochemical and petrological analyses. Comprehensive mineralogical analyses enabled to detect the following minerals-satellites of diamond associations: chrome-diopside, orange garnet, bright-crimson pyrope, picroilmenite, moissanite, corundum, black spinel, olivine, anatase and tourmaline (including black samples). These minerals do not rolled and oxidized that is an additional evidence of the neighboring occurrence of the indigenous rocks. Data of electronic microscopy show that the grains of (1) picroilmenite and (2) pyrope contain, respectively: (1) cobalt, chrome, magnesium and nickel and (2) chrome, magnesium and aluminum. This indicates that both picroilmenite and pyrope have the hyper-abyssal origin that also is an indicator of the possible occurring of diamondiferous pipes. List of secondary-importance satellite minerals includes feldspars, pyroxenes, magnetite, hematite, ilmenite, galenite, pyrite, limonite, mica, chromite, leucoxene, zircon, rutile, etc. These minerals (by their considering with the first group) are also indicators of diamond-bearing of the studied area. Identification of small plates of gold and silver as well as considerable traces of La, Ce, Th, Nb and Ta (Rare Earth Elements) also may be associated with the nearest kimberlite rock occurrence. The total number of recognized microdiamonds consists of more than 300 units; five diamonds (>1 mm) were identified (sizes of the most largest crystals are 1.2 and $1.35 \mathrm{~mm}$ ). Thus, on the basis of a set of geological-geophysical factors and identification of the mentioned minerals we can definitely estimate that the Makhtesh Ramon area is perspective for discovering diamondiferous rocks (kimberlite or lamproite pipes) as well as diamond crystals in loose deposits. Discovered silver-and gold-bearing and REE signatures may have independent importance.
\end{abstract}

Keywords: hot spot, diamonds, satellite minerals, gold, REE, geophysical signatures

\section{INTRODUCTION}

Three tectono-erosion cirques, termed "makhteshim" in Hebrew (sing. "makhtesh"): Makhtesh Ramon (largest), Makhtesh Gadol (intermediate) and Makhtesh Qatan (small) dispose in the anticlinal ridges in southern Israel (northern Negev). The makhteshim form closed valleys surrounded by steep cliffs 200-400 m high, with outlet engraved in the steep southeastern flanks of some largest asymmetric folds (Zilberman, 2000).

The Makhtesh Ramon erosional-tectonic depression (canyon), which is $40 \mathrm{~km}$ long and approximately $8 \mathrm{~km}$ wide, is situated $65 \mathrm{~km}$ southwest of the Dead Sea (Figure 1). Its formation terminated approximately $132 \mathrm{Ma}$ ago; i.e., during the Levantine tectonic phase (Katz and Eppelbaum, 1998). The subsequent origination of the Levantine marginal volcanic suture (Eppelbaum and Katz, 2012) promoted the accumulation of postcollisional trap rocks (alkaline basaltic, alkaline gabbroic, and kimberlitic associations). 


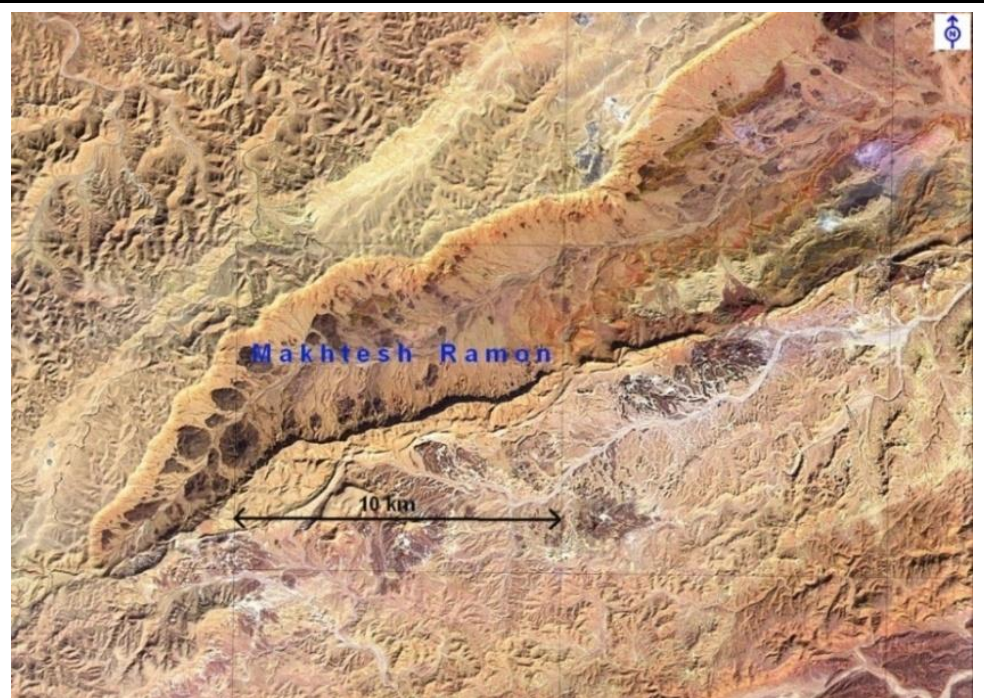

Figure 1. Makhtesh Ramon: Fragment of "The Holy Land Satellite DataBase Project" (the imagery was made by the data obtained from NASA's Landsat 5 satellite with French SPOT satellite)

Vent facies of the central-type Mahale Khahatsmaut depression contain peridotite xenoliths with spinel-bearing lherzolites (Stein et al., 1993). The presence of such rocks indicates significant depths of explosive volcanism. Magmatic rocks of the western Makhtesh Ramon Canyon are represented by picritic and olivine basalts, basanites, mantle xenoliths, melilites and alkaline picrites (Shimshilashvili and Yudalevich, 2005; Vapnik, 2005; Eppelbaum et al., 2006; Samoilov and Vapnik, 2007; Sharygin et al., 2012). Itamar (1988) described a polymetallic mineralization in Makhtesh Ramon.

As a result of integrated geological, geophysical and geochemical investigations along with geomorphological reconstructions, the western part of the Makhtesh Ramon Canyon (Figure 1) was chosen as the most promising area for the discovery of microdiamonds. Clastic rocks were sampled corresponding to both the early and late epochs of secondary erosion represented by Mesozoic (Lower Cretaceous Arod conglomerates) and Cenozoic (Middle Quaternary - recent alluvium) rocks, respectively. Samples from the near surface layer (depth interval $20-80 \mathrm{~cm}$ ) were concentrated by conventional tools in the geological base in Mizpe Ramon town and afterward were thoroughly analyzed mainly in the laboratories of the Moscow State University and Moscow State GeologicalProspecting University (Eppelbaum et al., 2002, 2003, 2006; Samykina et al., 2005; Surkov et al., 2008).

\section{BRIEF GEOLOGICAL BACKGROUND}

Over 200 dikes of basaltic and trachytic compositions intruded the sedimentary rocks in the Makhtesh Ramon area (Bayer and Reches, 1991). Most dikes are arranged in a complex (radial) system and a smaller number of dikes create two systems of NW-SE and NE-SW trends. The dikes are accompanied by many sills of similar composition. The smaller folds tend to form second-order structures superimposed on the larger folds and flexures (Garfunkel, 1993).The known magmatic outcrops at Makhtesh Ramon, Har Arif and Qrief en Naqa belong two different magmatic phases, preand post-dating a sub-Cretaceous unconformity (Garfunkel and Katz, 1967; Starinsky et al., 1980; Lang and Steinitz, 1985; Baer et al., 1995; Gvirtzman et al., 1994).

Maximal magmatism in the region occurred approximately $120 \mathrm{Ma}$ ago, which corresponds to the epoch of global tectono-thermal activation. Larson (1995) termed this epoch the Middle Cretaceous maximum in the development of upper mantle hot spots and associated it with high development of diamond-bearing kimberlites during the Mid-Cretaceous. In the Makhtesh Ramon area, this stage is reflected in central-type volcanoes composed of lava flows, eruptive breccia, and tuffs that suggest wide development of explosive volcanism in the Middle Cretaceous (Lang and Steinitz, 1989; Segev et al., 2005).

Chang and Lee (2011) presented tectonic map with three large mantle plumes in the Near and Middle East, and one of the plumes completely covers the makhteshim family location.

Ben-Aviaham and Ginzburg (1990) and Ben-Avraham et al. (2002) have been recognized Negev, Judea-Samaria, Galilee-Lebanon, Levant Basin, Cyprus and Anaximander terranes in the Easternmost Mediterranean (Figure 2). It should be noted that makhteshim occur at the boundary between the Negev and Judea-Samaria terranes, i.e. in the tectonically weakened zone (see Figure 2). 


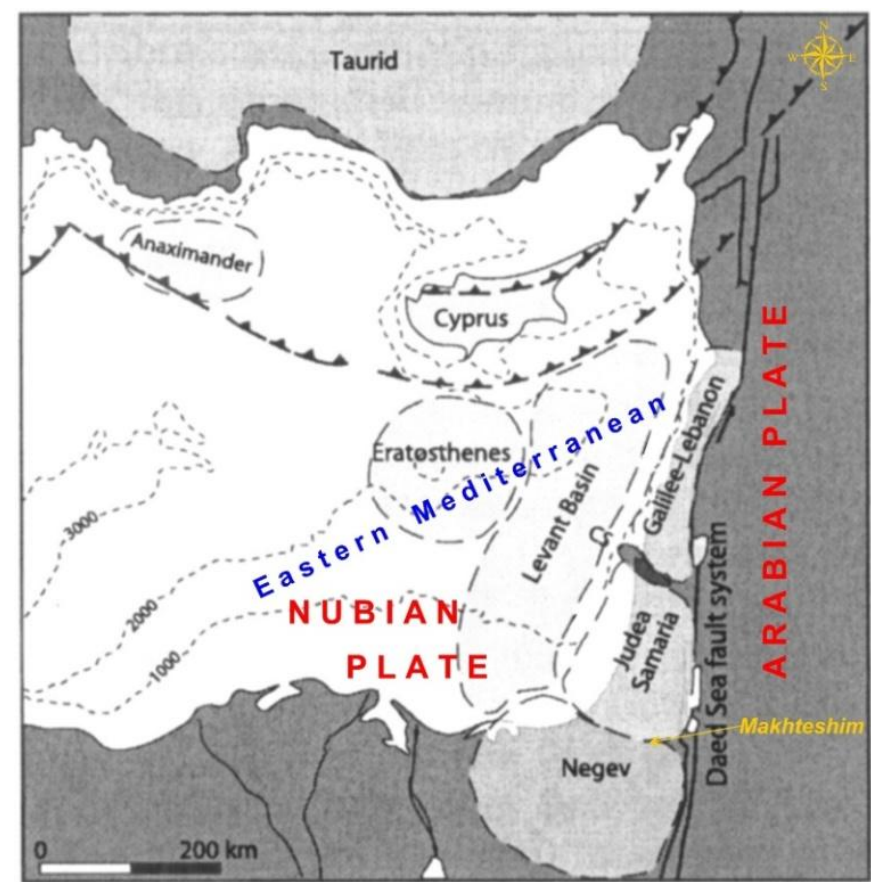

Figure 2. Location of terranes in the Easternmost Mediterranean (after Ben-Avraham and Ginzburg, 1990; Ben-Avraham et al., 2002) with some additions

Geological map of Makhtesh Ramon area (after Sneh et al., 1998) (Figure 3) shows complex and mosaic distribution of sedimentary rocks and magmatic and metamorphic associations. The stratigraphic sequence along the Ramon lineament ranges from the Middle Triassic to the Middle and Late Eocene (Bentor et al., 1965; Benjamini, 1980; Sneh et al., 1998). At the same time, the most significant role play here Early Cretaceous igneous rocks. The volcanic sequence in the western Makhtesh Ramon area overlies $55 \mathrm{~m}$ of Aptian sediments (Gvirtzman et al., 1996) and reaches its maximal thickness of $\sim 200 \mathrm{~m}$ there (Garfunkel and Katz, 1967). At Ma'ale Ramon the volcanics are 37 m thick and disappear in the easternmost part of Makhtesh Ramon (Hall et al., 2005).

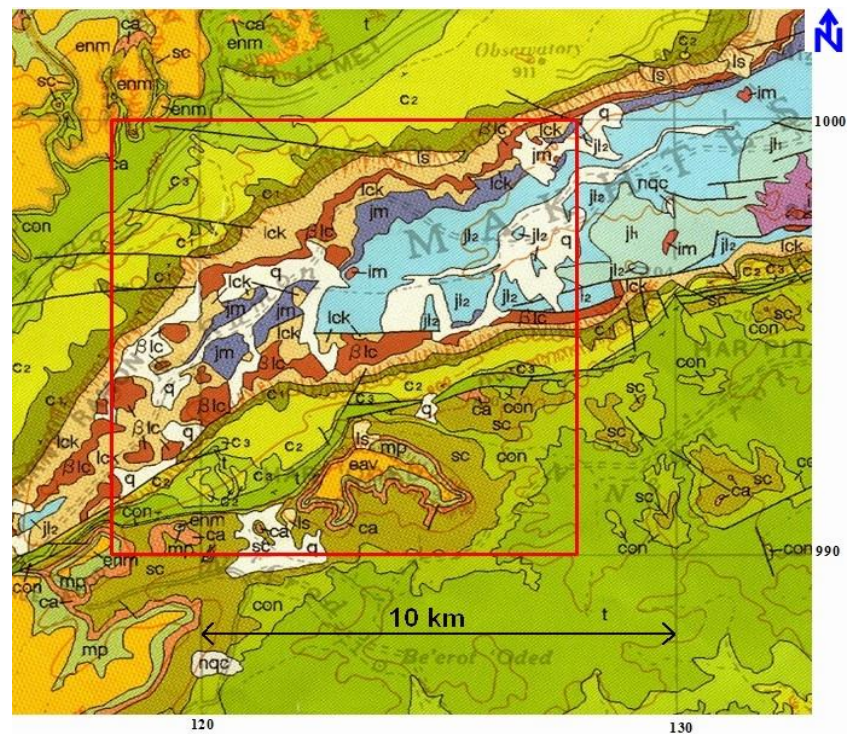

Figure 3. Geological map of Makhtesh Ramon. Fragment of the geological map of Israel. Scale: 1: 200,000, Sheet No. 3 (Sneh et al., 1998). Red square indicates the area under study

Mt. Arod (diameter 1500-2000 m, height about $180 \mathrm{~m}$ ) located in the western Makhtesh Ramon is an important tectonic element of the area. It is an Early Cretaceous volcano, re-exposed by erosion during the incision of Makhtesh Ramon. Mt. Arod is composed of basanitic-nephelenitic rocks with a lava lake in the center.The mountain (hill) is surrounded by tuffs and lava flows, and intruded by subvolcanic stocksand dikes, and a diatreme (Eyal et al., 1996). Interestingly to note that diatreme (volcanic pipe formed by a gaseous explosion) is frequently associating with the kimberlite magmatism. 

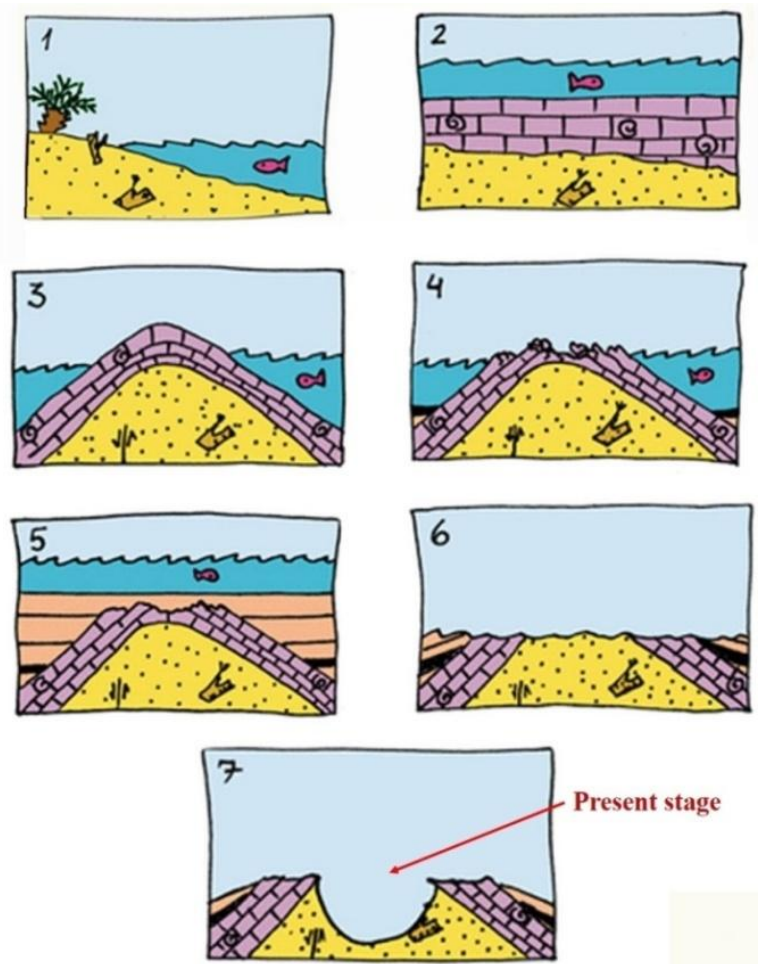

Figure 4. Stages of tectono-structural evolution of the Makhtesh Ramon area (after Avni (2001) and Geological Survey of Israel)

Figure 4 (after Avni (2001) and Geological Survey of Israel) clearly displays a history of tectonic evolution of the Makhtesh Ramon area. Description of these seven stages is given after Avni (2001) with some simplifications:

1. In the beginning (110 million years ago), this area had rivers and lakes, which developed near a shallow sea. Sandstone rocks (Hatira formation) were deposited onto this continental environment (Lower Cretaceous).

2. A shallow sea with a dense population of life forms flooded the area 90-100 million years ago. The Cenomanian and Turonian rocks cover the top of the Ramon anticline.

3. The rocks folded and formed an anticline ( 80 million years ago) along the length of the Ramon fault, an ancient underground geological fault which was "awakened" by tectonic movements. The area was later flooded by a deeper sea, in which friable limestone rocks were formed (Senonian formation). The conglomerate rock found on top of the limestone, at the base of the anticline, was produced under continental conditions, evidence that the peak of the anticline protruded like a continental island above the rest of the anticline, which was still under water. Because the top of the anticline was worn away, there is no conglomerate rock on the peak.

4. The Ramon anticline continued to rise (60-70 million years ago) along the line of the Ramon fault, with strata of chalk and flint (Senonian formation) and chalk with some clay and phosphates (Maastrichtian formation). Sands and conglomerates that were washed away from the top of the anticline during strong erosion processes were deposited around the anticline.

5. During the Eocene era (40-50 million years ago), the whole area flooded, including the Ramon anticline and the primary makhtesh. The limestone rocks that were deposited in this sea were recognized on the western part of the Ramon anticline and on the Avdat plateau.

6. The sea level dropped and the Ramon anticline continued to rise (30 million years ago).The peak of the Ramon anticline was largely eroded, exposing a large sandstone core, which had precipitated during the early stages of the formation of the makhtesh.

7. The rivers have been developing and creating Makhtesh Ramon (20 million years ago - present). The fact that today the heights of the Ramon Ridge stand more than 1,000 meters above sea level is evidence of a marked rise in the ridge. As the ridge rose, it slanted slightly to the northeast (towards the Arava), as the result of the development of the deep valley of the Dead Sea Transform. The great 
difference in height and the slanting of the ridge led to vigorous erosion and the undermining of the soft sandstone strata, which were carried from the Ramon Ridge to the Arava. The erosion of the inner parts of the ridge created Makhtesh Ramonas we observe is today.

\section{Regional Geophysical Data Analysis}

It is assumed that events of regional kimberlite magmatism are associated with some parameters of Earth's crust and lithosphere and some their physical properties and presence of linear deformations on the mantle surface and in the Earth crust (Milashev, 1974; Kaminsky et al., 1995; Mitchell, 1995; Morgan, 1995; Kutinov and Chistova, 2016).

The low heat flow $\left(\sim 35 \mathrm{~mW} / \mathrm{m}^{2}\right)$ in southern Israel is a positive indicator of the possible diamond potential in the area (Eppelbaum et al., 2006). It is a well-known fact that commercial diamond deposits were found exclusively in the regions with heat flow distribution less than $40 \mathrm{~mW} / \mathrm{m}^{2}$ (Kaminsky et al., 1995; Morgan, 1995; Kutinov and Chistova, 2016).

Comparatively large depth to the Moho discontinuity in the Makhtesh Ramon area $(\sim 34 \mathrm{~km})$ (Figure 5) (Eppelbaum and Pilchin, 2006) is as well auspicious signature (Morgan, 1995; Cherepanova et al., 2013; Kutinov and Chistova, 2016).

Another significant geophysical indicator is a large depth to the Curie Point isotherm (Morgan, 1995; Condie, 2001). Calculated Curie point isotherm for the makhtes him are a location consists of $38 \mathrm{~km}$ (Eppelbaum and Pilchin, 2006) (Figure 6) that also is a positive indicator (cool lithosphere).

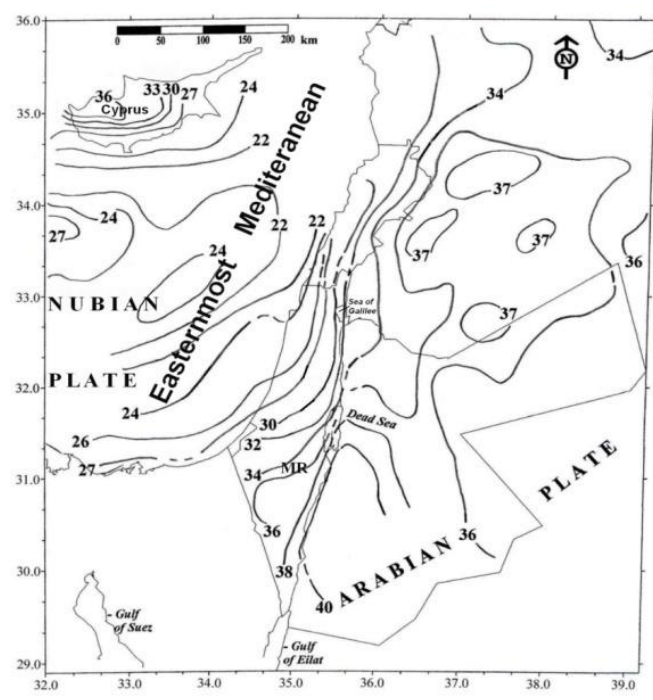

Figure 5. Map of Moho discontinuity of the Easternmost Mediterranean (after Eppelbaum and Pilchin, 2006, with small modifications). MR, Makhtesh Ramon

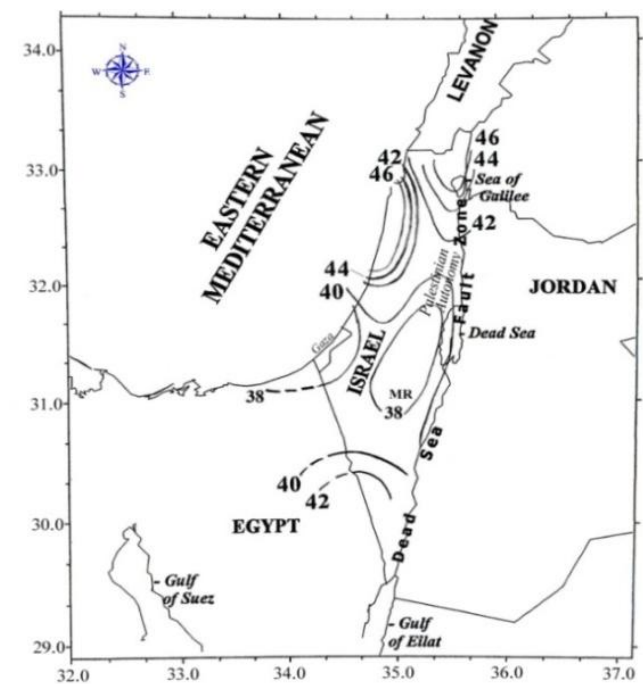

Figure 6. Curie map of Israel (after Eppelbaum and Pilchin, 2006, with small modifications). MR, Makhtesh Ramon 
Finally, last positive regional geophysical indicator is comparatively low depth of the crystalline basement occurrence (Morgan, 1995; Nixon, 1995). In the Makhtesh Ramon area the depth of crystalline basement, according to Rybakov and Segev (2004), consists of 3.3-3.5 km.

From combined examination of two last indicators follows that a large thickness of crystalline basement is also favorable factor. It is also can be considered as positive signature (Morgan, 1995; Cherepanova et al., 2013). It is easy to calculate that in the area under study the thickness of crystalline basement exceeds $30 \mathrm{~km}$.

Many authors (e.g., Green and Gueguen, 1974; Mitchell, 1986; Griffin, 2008) note a possible great role of mantle diapirism in the kimberlite matter transportation from the depth to the earth's surface. From this point of view is necessary to underline that the greatest in Israel magnetic anomaly 'Hebron' ( 110 km NNE of the Makhtesh Ramon) was interpreted as a probable mantle diapir (Eppelbaum et al., 2005).

Figure 7A shows airborne magnetic map of western Makhtesh Ramon overlaid onsimplified geological map (after Gvirtzman and Weinberger, 1994) and two interpreting magnetic profiles. Results of magnetic field modeling (semi-automatic software developed at the Moscow State Univ. was applied) along profile II - II are presented in Figure 7B. It shoud be noted that the airborne magnetic observations (taking into account altitude and spasing of the airmagnetic survey) reflect only large anomalous bodies (at least two buried targets have expressed quasi-kimberlite structure).

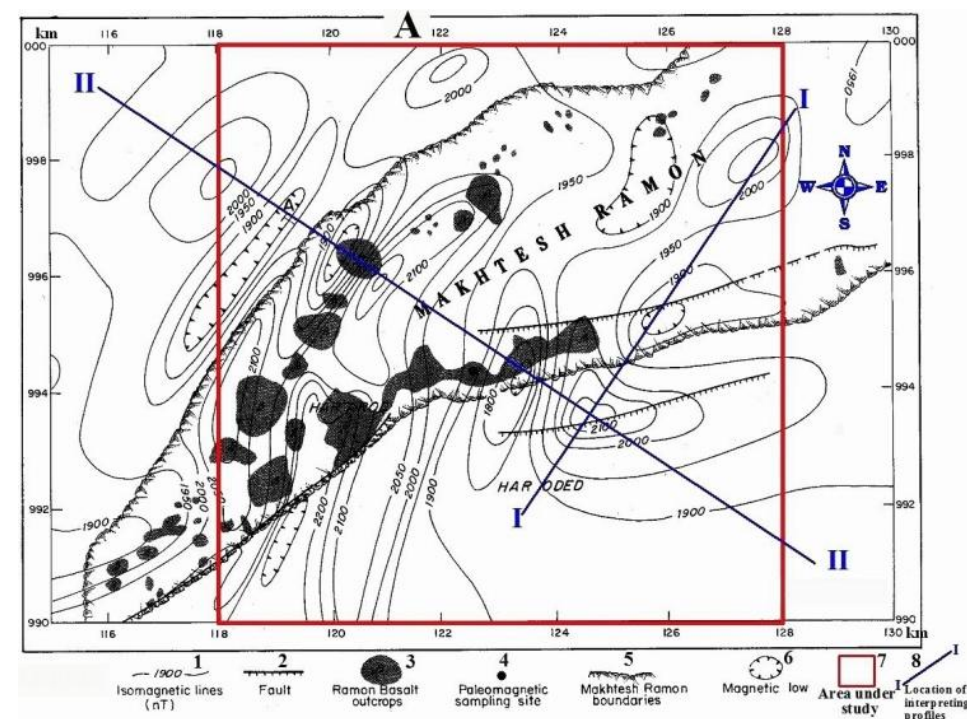

Figure 7A. Aeromagnetic map (flight altitude: $1000 \mathrm{~m}$, spasing: $2000 \mathrm{~m}$, IGRF has been removed) of the western Makhtesh Ramon overlaid on geological map (after Gvirtzman and Weinberger, 1994) with location of two interpreting profiles

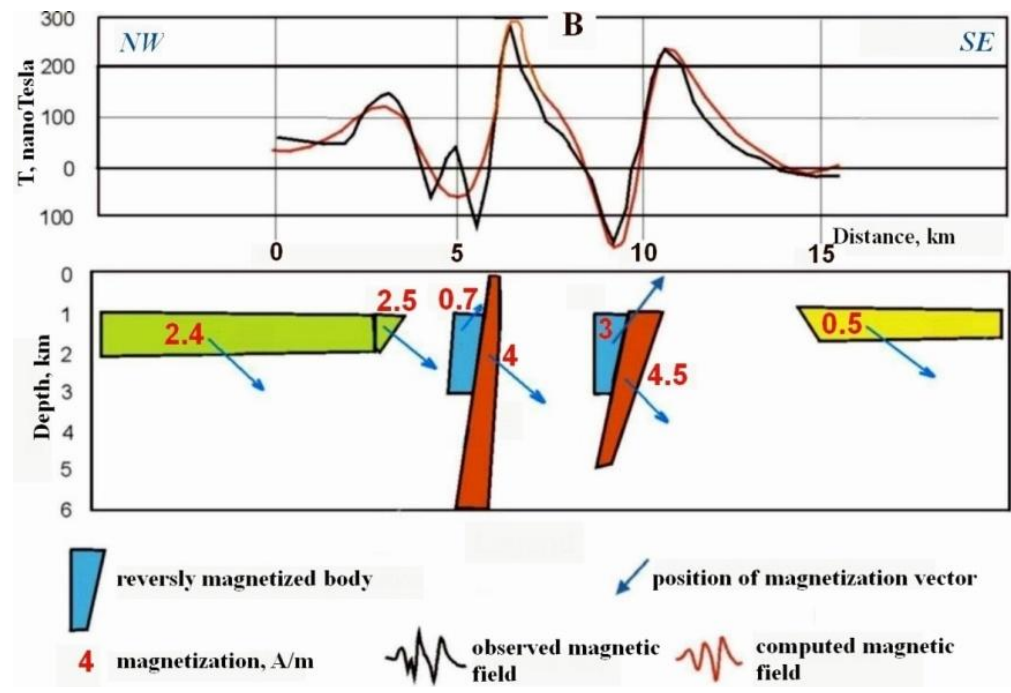

Figure 7B. Results of magnetic field modeling along profile II - II in Makhtesh-Ramon (location of this profile is shown in Figure 7A)(after Eppelbaum et al., 2002, with modifications) 
Concerning the confinement of the kimberlite magmatism to zones of regional linear deformations. Several investigators (e.g., Ben-David and Mazor, 1988; Zilberman, 1991; Ben-David et al., 2002) have suggested that the makhteshim structures were developed during the Middle to Late Cenozoic in response to formation of the Dead Sea Transform Zone (see figure2).

\section{Detailed Geophysical Data Analysis}

\subsection{Magnetic Data Analysis}

Magnetic pattern of the Makhtesh Ramon area is very complex (Folkman and Yuval, 1976; Gvirtzman et al., 1994) since various magnetized rocks (tephrites, basanites, olivine basalts, quartz syenites) occurring at different depths contribute their diverse effects to the observed field.

Detailed analysis of the magnetic data (including quantitative interpretation and 3D modeling (developed methodologies for complex physical-geological conditions are described in detail in Eppelbaum and Khesin (2012)) indicates presence of near-surface occurring (from eight to fifty meters) bodies having a form of thin beds and 'inverse carrot' (Eppelbaum et al., 2003; 2006).

Observed magnetic map of the area I is unclear because the local anomalies are masked by an intensive regional background. Results of the gradient operator application for the total magnetic field processing in area I are shown in Figure 8. Even simple visual analysis of this map indicates presence of series of ring structures occurring at low depths.

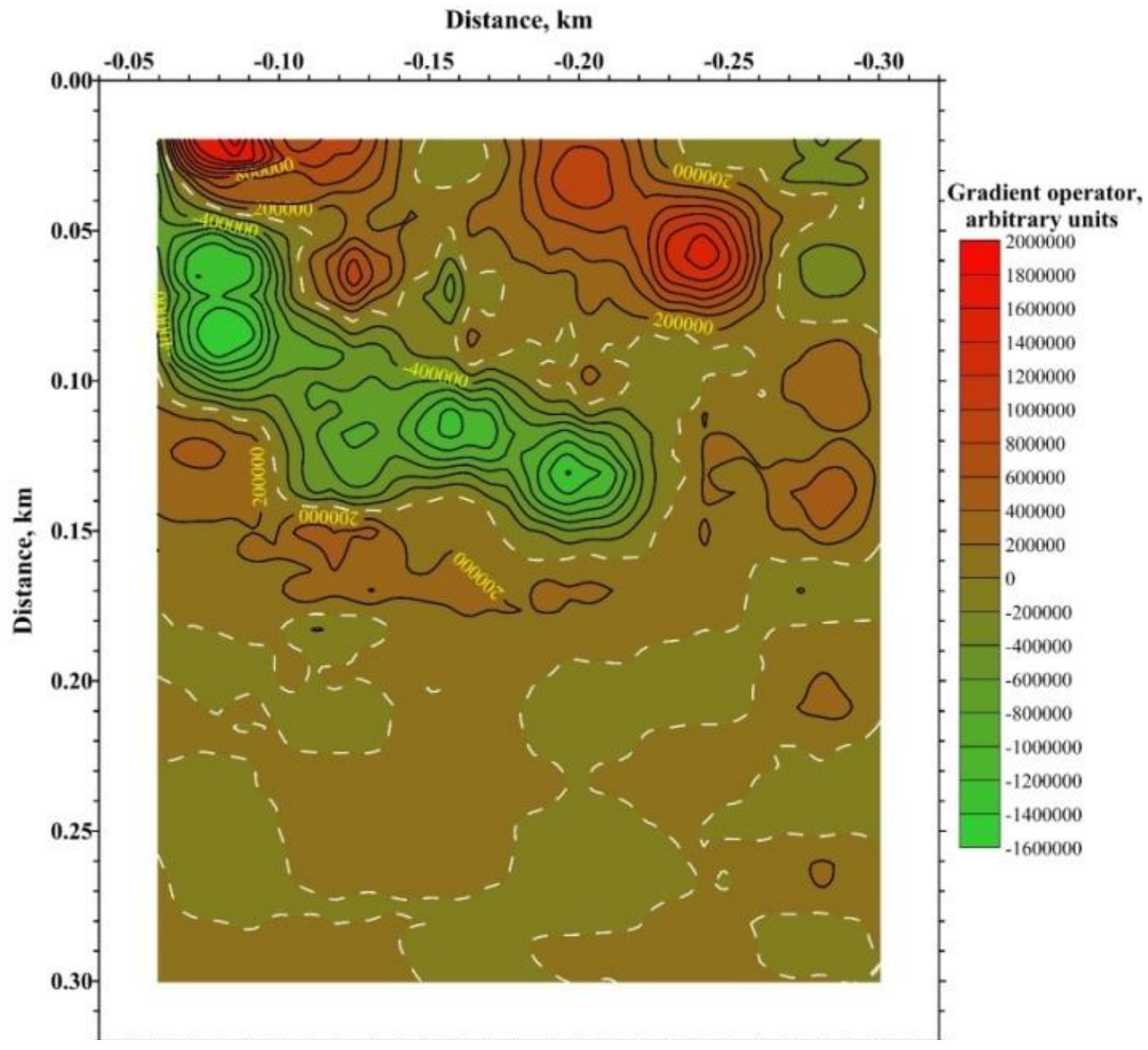

Figure 7. Results of the total magnetic field processing by gradient operator in area I

An interesting example of magnetic data re-interpretation is displayed in Figure 9. Initial geologicalgeophysical data analysis (Baer et al., 1989) proposed that source of this anomaly is a buried sill (Figure 9). However, re-interpretation of this anomaly (Eppelbaum et al., 2006) allowed to conclude that a kimberlite pipe (classical kimberlite pipe model is presented in Haggerty (1995)) is the most suitable model. 


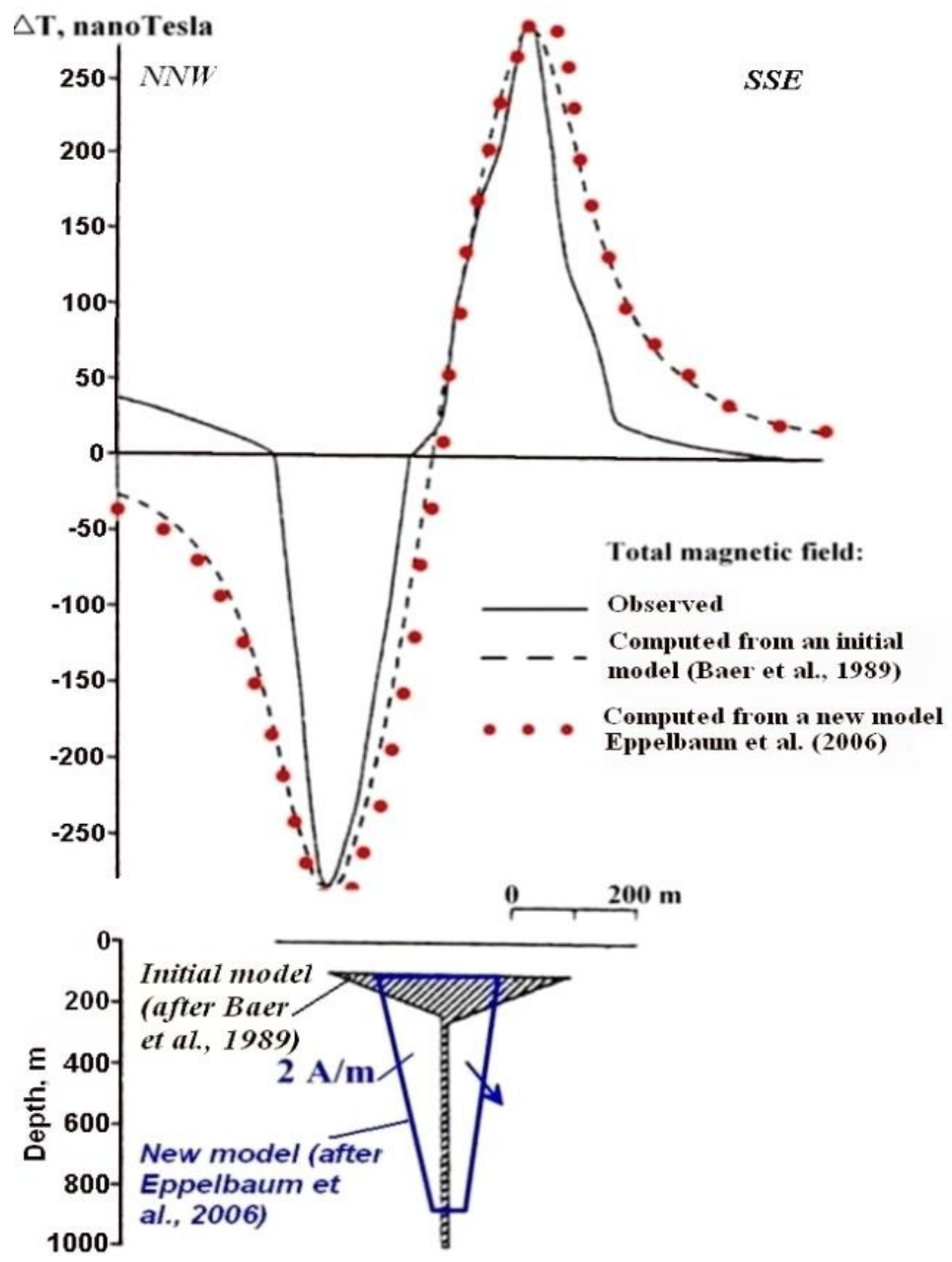

Figure 8. Results of magnetic data interpretation in the eastern part of Makhtesh Ramon area (initial data after Baer et al., 1989; revised model - after Eppelbaum et al., 2006)

Gvirtzman et al. (1994) analyzed sizable magnetic anomalies in the Makhesh Ramon area and south of it. The authors associated examined anomalies with large magmatic bodies of the Late Jurassic Early Cretaceous age of apparently basaltic consistency. Interestingly that the models of disturbing bodies developed on the basis of 2.5D magnetic field modeling (Gvirtzman et al., 1994) in many cases are very similar to the classic models of kimberlite pipes (Haggerty, 1995; Mitchell, 1995).

\subsection{First Paleomagnetic Map Compilation}

It should be noted that sometimes paleomagnetic data are of high importance since they can give results which may be not received by any other geological-geophysical methods (Eppelbaum, 2015). For compiling the first paleomagnetic map of Makhtesh Ramon the available paleomagnetic, radiometric and geological data were examined: Garfunkel and Derin, 1988; Lange and Steinitz, 1989; Baer and Reches, 1991; Baer, 1993; Eyal et al., 1996; Gvirtzman et al., 1996; Segev, 2000; Segev et al., 2005, 2009, etc. The oldest preaccretional dikes (Omolon paleomagnetic zone) trend south-north and the dikes of accretional stage (upper part of Gissar paleomagnetic zone) trend east-west (Figure10). The eastern margins of preaccretional and accretional dike complexes and other magmatic bodies have older ages compared to the western margins. Ages of the eastern Omolon zone are 165.7 Ma; on the western margin 151.4 Ma are reported. Within the Gissar zone, ages are zoned from east to west from 142.5 Ma to $126.8 \mathrm{Ma}$. Various volcanic bodies of postaccretional stage (Jalal paleomagnetic zone) are discordant relative to dike orientations in the Omolon and Gissar zones. Most magmatic bodies of the Jalal zone trend from WSW to ENE (Figure 10). Paleomagnetic analysis carried out by Gvirtzman et al. (1996) in the SWW part of zone Jalal (this paleomagnetic zone is characterized by predominant direct polarity) indicates that all magmatic sample determinations show direct polarity except for the Mt. Arod area where both direct ('younger' flows) and inverse ('older flows') polarities were registered. It should be noted that the Gissar paleomagnetic zone is by numerous approximately equivalent alternation of direct and reverse polarities (this fact must be taken into account by magnetic anomalies qualitative and quantitative examination). 


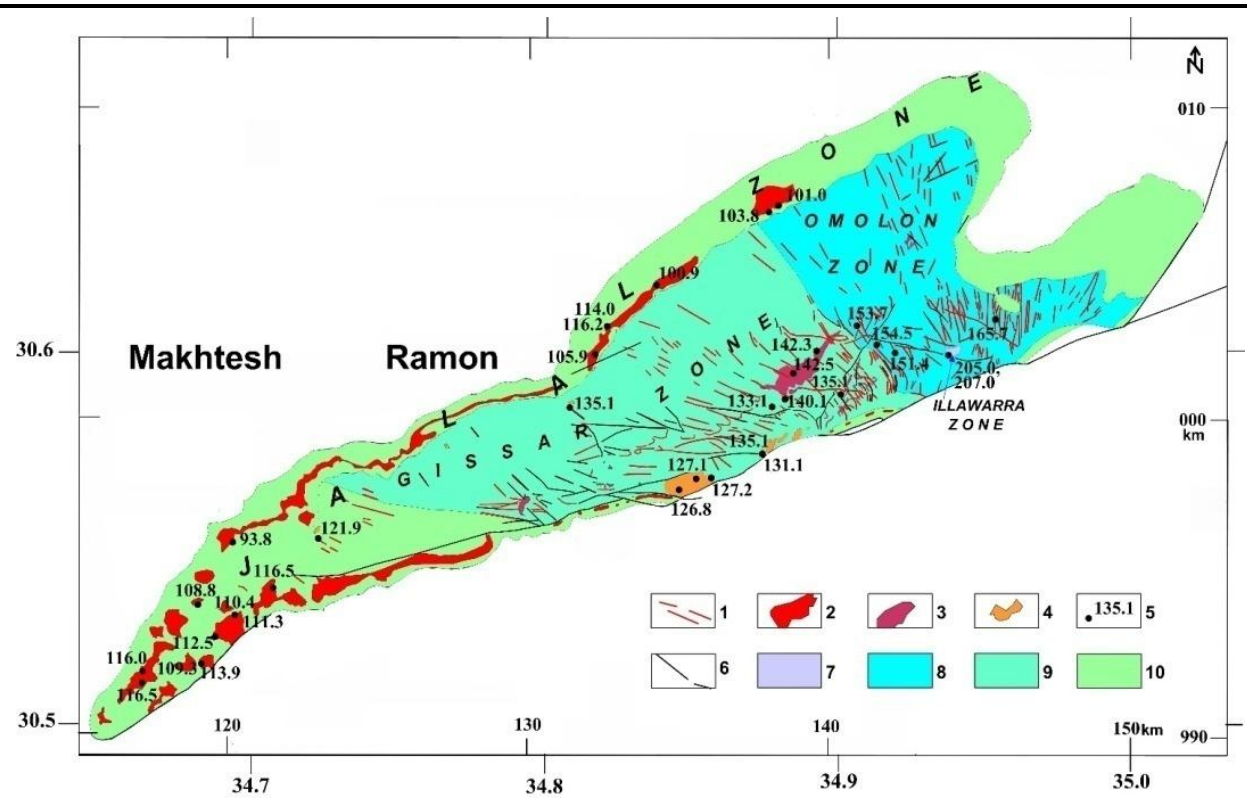

Figure 10. Geodynamic-paleomagnetic map of magmatic formations of Makhtesh Ramon area (after Eppelbaum and Katz, 2015, with small modifications)

(1) basalt dikes, (2) basalt flows and volcaniclastic rocks, (3) gabbroic-andesitic rocks, (4) alkaline rocks; (1-4 after Garfunkel and Katz (1967), Zak (1968), Baer and Reches (1991), Baer (1993), Baer et al. (1995), Sneh et al. (1997)), (5) radiometric age of magmatic rocks (after Lang and Steinitz, 1989; Segev, 2000; Segev et al., 2005), (6) faults; paleomagnetic zonation within the magmatic complexes (7-10): (7) Illawarra, (8) Omolon, (9) Gissar, (10) Jalal

\subsection{Self-Potential Data Examination}

In the developed self-potential map of area I (Figure 11) an anomalous zone is contoured (white dash line) which is a good agreement with the magnetic susceptibility map examination (Eppelbaum et al., 2003). Quantitative interpretation of self-potential anomalies performed using advanced methods developed in magnetic prospecting (Eppelbaum et al., 2004) allowed to estimate a depth of the upperedge of the buried target: $\cong 25-30 \mathrm{~m}$.

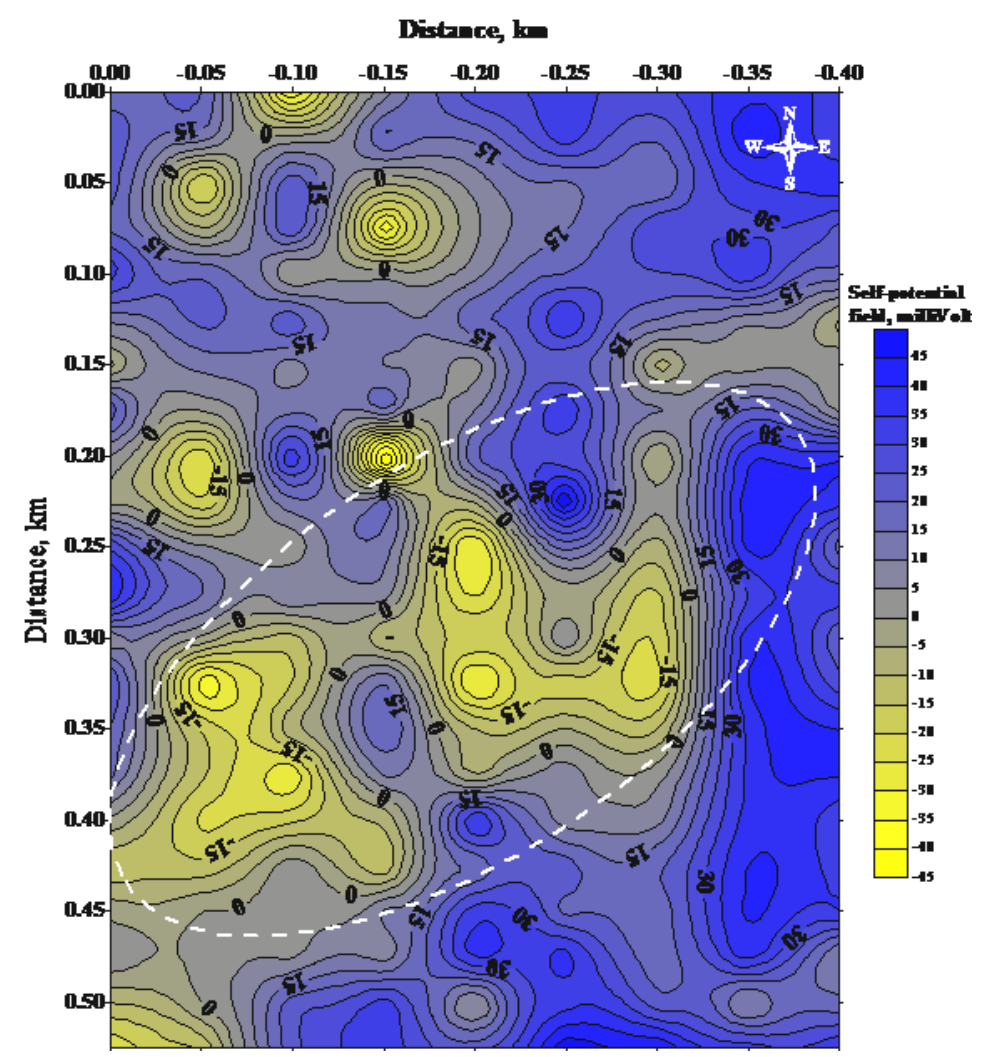

Figure 11. Results of self-potential method application at the area I of the western Makhtesh Ramon 


\subsection{Application of ionselective electrods}

An ionselective electrod method (e.g., Nowak, 2010) is based on applying a set of calibrated ionselective electrodes $\left(\mathrm{Cl}^{-}, \mathrm{Br}^{-}, \mathrm{I}^{-}, \mathrm{Na}^{+}, \mathrm{K}^{+}, \mathrm{NH}_{4}^{+}, \mathrm{NO}_{3}^{-}, \mathrm{NO}_{2}^{-}, \mathrm{Ag}^{+}, \mathrm{S}^{2-}, \mathrm{Cu}^{2+}, \mathrm{Cd}^{2+}, \mathrm{Pb}^{2+}, \mathrm{Hg}^{2+}\right.$, $\mathrm{Ca}^{2+}, \mathrm{Ba}^{2+}\left(\mathrm{SO}_{4}^{2-}, \mathrm{ClO}_{4}^{-}, \mathrm{ReO}_{4}^{-}, \mathrm{F}^{-}, \mathrm{AuCl}_{4}^{-}, \mathrm{CNS}^{-}, \mathrm{Ca}^{2+}+\mathrm{Mg}^{2+}, \mathrm{Ph} \mathrm{Ph}_{\text {int }}, \mathrm{Eh}\right)$ for studying soil mixtures (loose deposits) "in situ" or laboratory conditions. Among these electrodes, a set of parameters associated with kimberlite pipes has been picked out. We present here only $\mathrm{Na}^{+}$and $\mathrm{Ba}^{2+}$ maps (Figures 12 and 13, respectively), but other ionselective electrode employment also gave positive results.

Kimberlite rocks or products of their destruction contain heightened contents of $\mathrm{Na}^{+}$(Ahrens et al., 1975; Mitchell, 1986, 1995), which also may be utilized as searching indicator. Measurements using $\mathrm{Na}^{+}$electrodes show a direct correlation between number of ions and value of registered potential. Developed map of $\mathrm{Na}^{+}$(Figure 12) enabled to delineate a fault oriented SW - NE across the points $0 / 150,50 / 375,100 / 325,150 / 300,200 / 275,300 / 225$. We should note that the fault is traced almost in all developed ionselective maps. The area of the proposed location of kimberlite pipe is contoured by a heightened $\mathrm{Na}^{+}$contents.

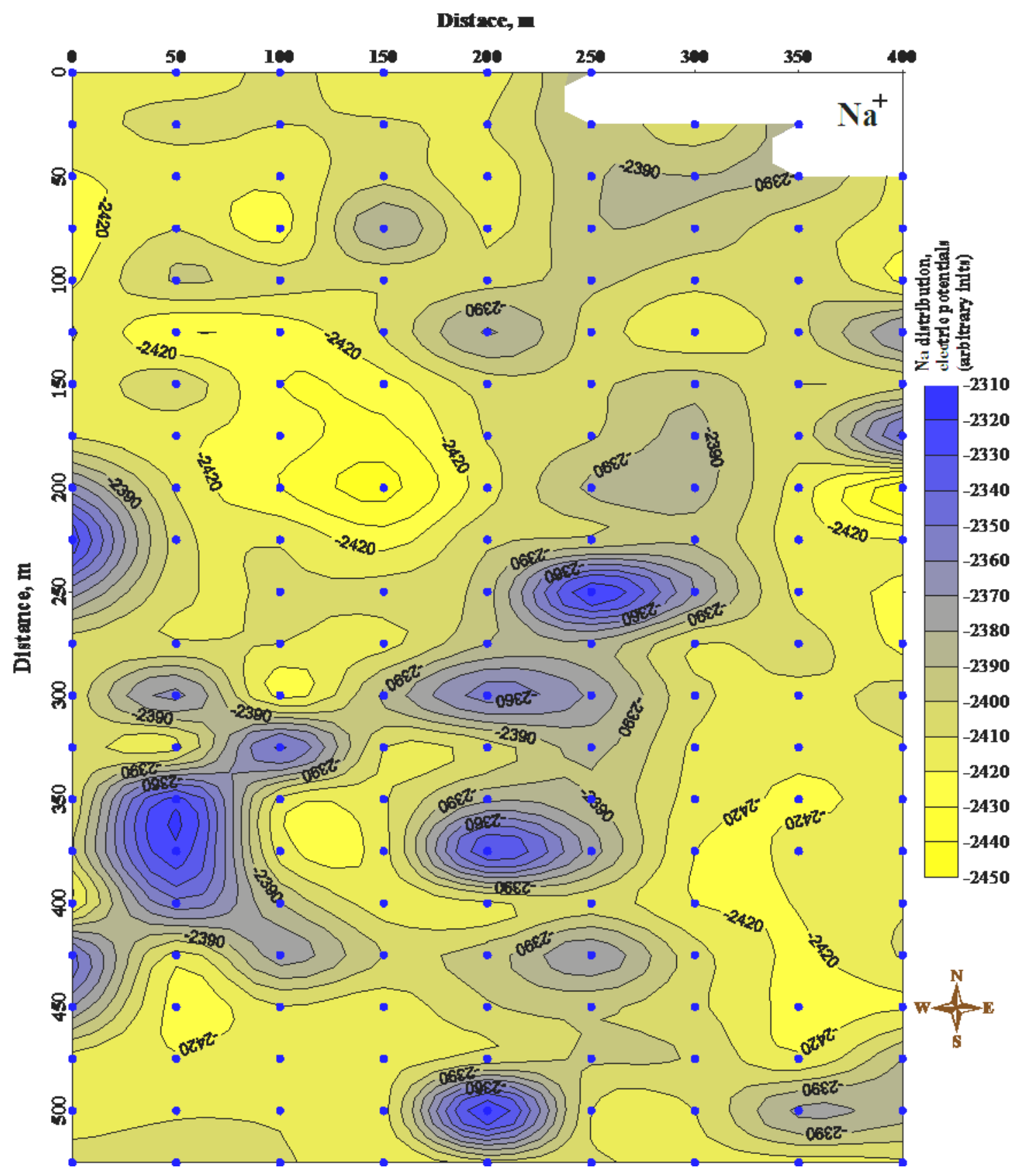

Figure 12. Area I of the western Makhtesh Ramon. Map of $\mathrm{Na}^{+}$observations 
Barite is one of known kimberlite-generative minerals (Bobrievich et al., 1959; Ahrens et al., 1975; Mitchell, 1995). The most part of barite is concentrated in the upper part of kimberlite pipe (Bobrievich et al., 1959). In the developed map of barite isopotentials $\mathrm{Ba}^{2+}$ (Figure 13) a fault is neatly traced. Anomalous zones point out to the most perspective areas for near-surface well drilling or bore-pit excavation.

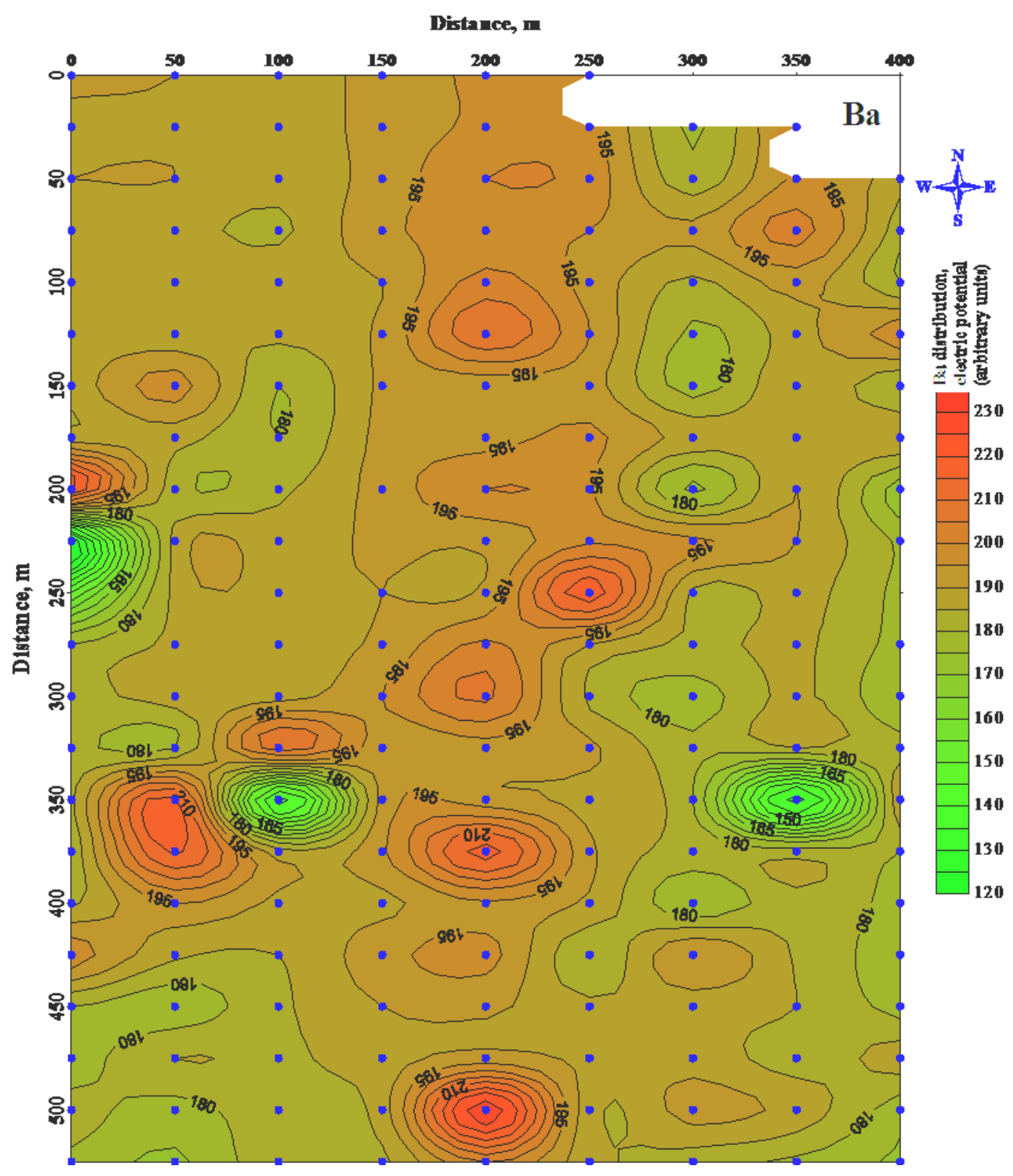

Figure 13. Area I of western Makhtesh Ramon. Map of $\mathrm{Ba}^{2+}$ observations

\section{Mineralogical, Petrological and Geochemical data Analysis}

It is interestingly to note that Kaminsky et al. (1995) in the scheme 'Diamondiferous territories of the World' have distinguished an Eastern Mediterranean diamondiferous province.

The first microdiamond in Israel was discovered in the Negev Desert $30 \mathrm{~km}$ north of Makhtesh Ramon (Israel) in the Cretaceous/Paleogene boundary iridium layer and was attributed to a meteorite fall (Flexer et al., 1988b). However, the habit, size, and characteristic impurities in the microcrystal suggest that it was washed out from diamondiferous igneous rocks.

Samples from the near surface layer were withdrawn in the western Makhtesh Ramon (depth interval $10-80 \mathrm{~cm}$ ) (some work process is shown in Figure 14), processed in the temporary basis in Mizpe Ramon town and later thoroughly analyzed in laboratories of the Moscow State University and Moscow State Geological-Prospecting University (Eppelbaum et al., 2002, 2003; Samykina et al., 2005; Surkov et al., 2008). 


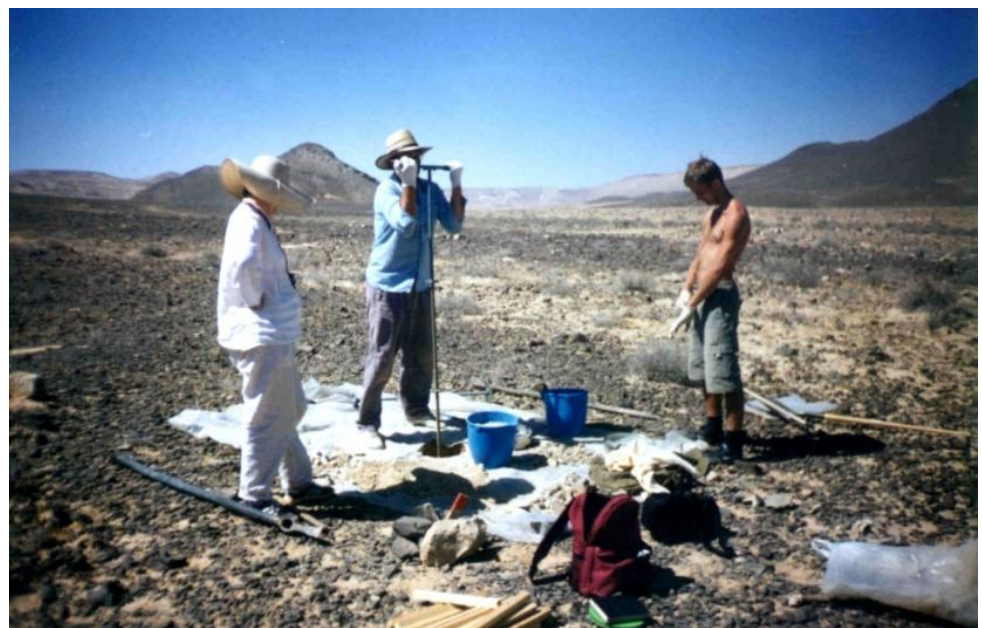

Figure 14. Selection of near-surface samples by the way of hand drilling in the western Makhtesh Ramon

Minerals of the diamondiferous association found in these samples can be divided into two groups. The first group includes chromediopside (e.g., Figure 15a and 15b), orange garnet, bright crimson pyrope (e.g., Figure 16), picroilmenite, chromespinel (e.g., Figure 17), olivine, moissanite, perovskite, anatase, corundum, titanomagnetite, and tourmaline (including black species). It should be noted that this mineral list includes almost all the main satellite minerals of diamond. The total content of these minerals is very high (in the $150 \mathrm{~kg}$ of concentrate more than 15000 grains were identified).

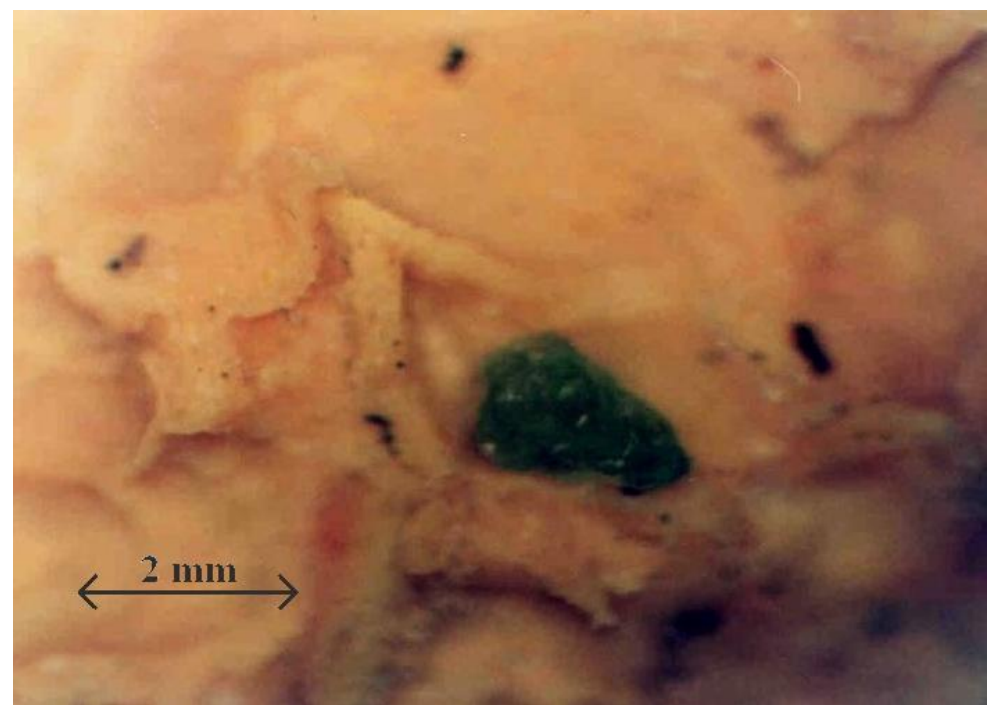

Figure 15a. Crystal of chromediopside No. 1243 withdrawn in selected probes of the Makhtesh Ramon deposit

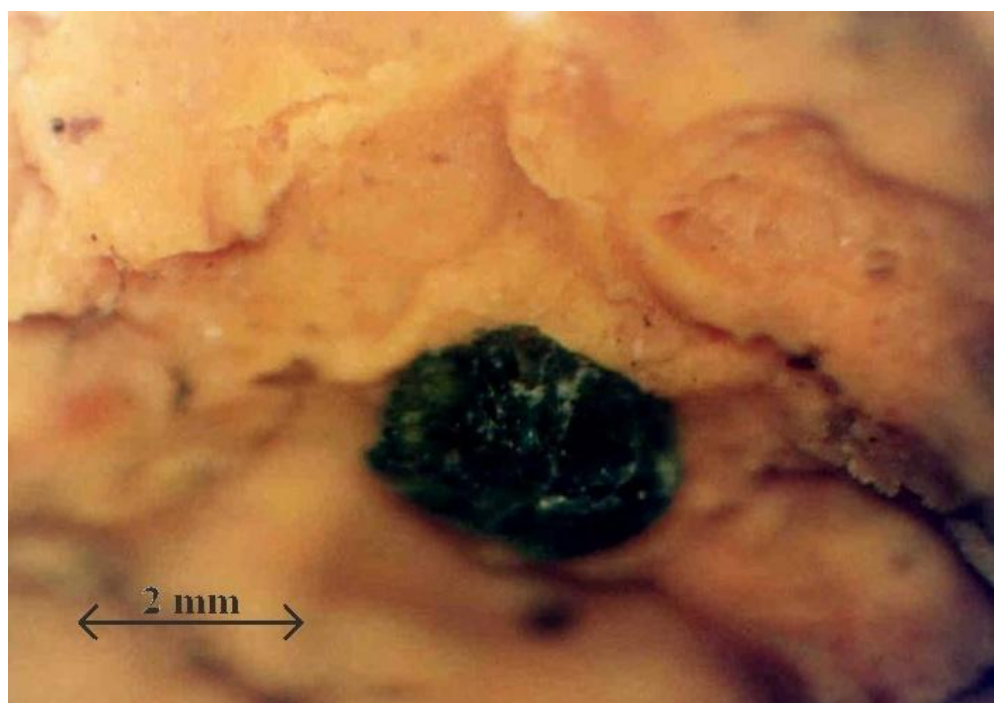

Figure 15b. Crystal of chromediopside No. 1517 withdrawn in selected probes of the Makhtesh Ramon deposit 


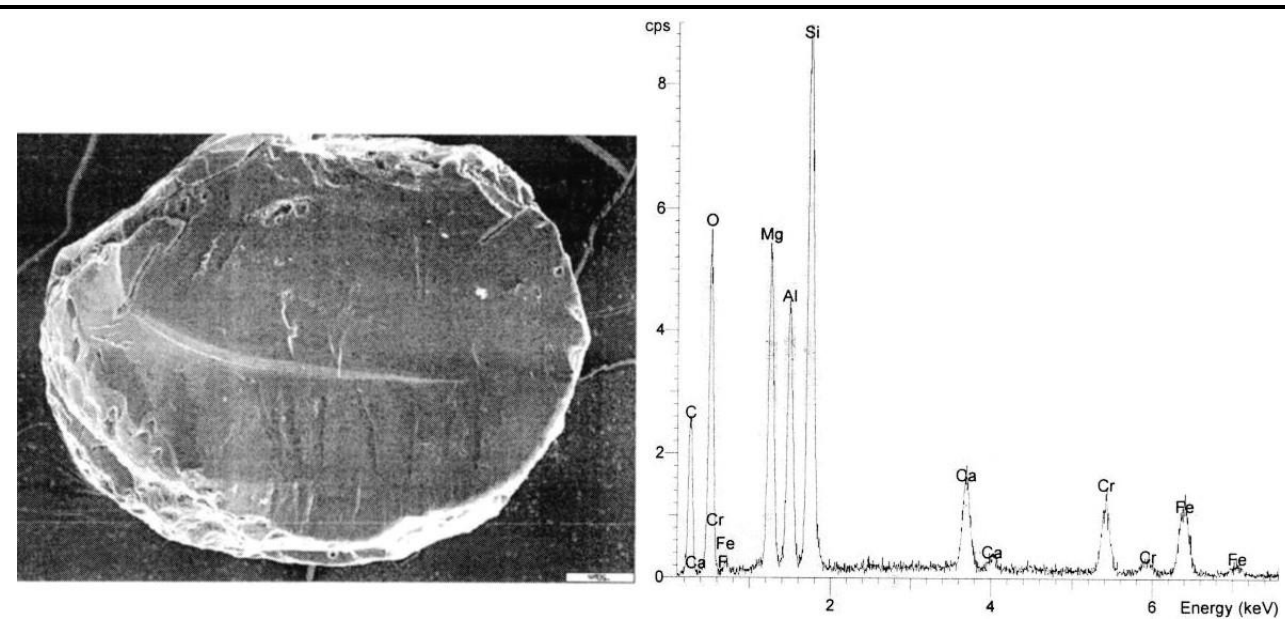

Figure 16. Pyrope: back-scattered electron image (left) and electrodispersion spectrum (right)

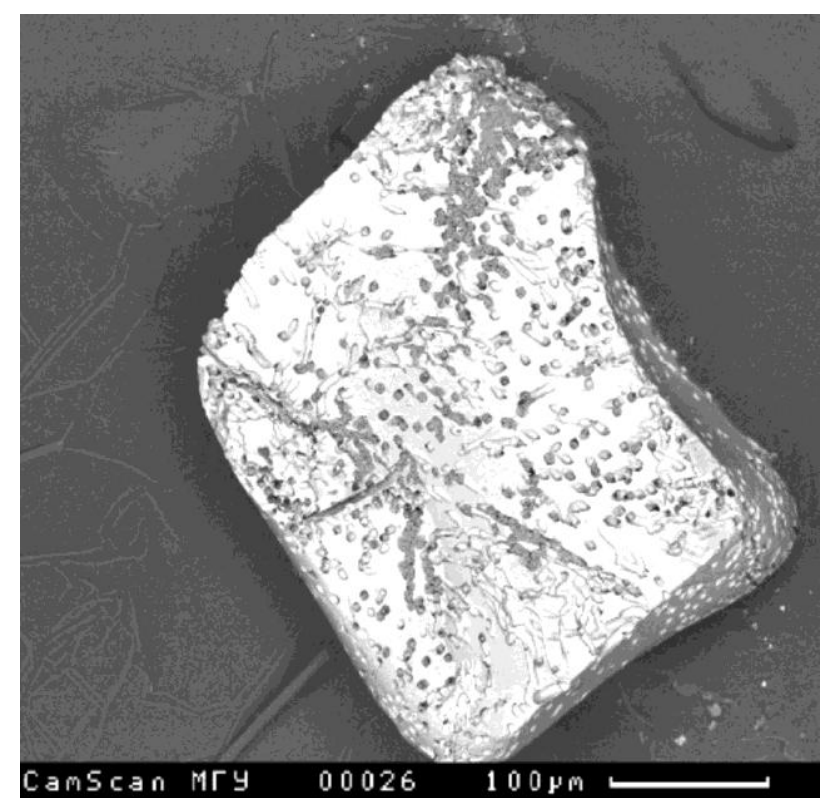

Figure 17. Chromespinel. Back-scattered electron image

Chromediopside is well-known satellite mineral of diamond. Orange garnet, bright crimson pyrope, and tourmaline are also indicators of the occurrence of diamondiferous associations in this area. Corundum and moissanite are even better satellite minerals in this regard (Mitchell, 1986; Ilupin et al., 1990; Kharkiv et al., 1997). Most of the associated mineral grains are not rounded or oxidized, suggesting the proximity of bedrock diamondiferous associations. Moissanite ( $\mathrm{SiC})$, widely known as a rare high-pressure mineral of mantle origin, is an important window into the oxygen deficiency processes in the deep Earth. Moissanite samples were found both in Makhtesh Ramon (Eppelbaum et al., 2006) and Qishon Valley (northern Israel) (Eskel et al., 2007). For the first time 4H SiC polytype was recently found in situ in the QishonValley (Mukhin et al., 2015). Comprehensive examination of this sample indicates mantle origin of $4 \mathrm{H} \mathrm{SiC} \mathrm{polytype} \mathrm{and} \mathrm{possible} \mathrm{occurrences} \mathrm{of} \mathrm{redox} \mathrm{conditions}$ in significantly larger volume of lithosphere in Israel than it was thought before. This is known that a thick lithosphere is a prominent positive signature (altogether with other indicators) for discovery of diamond-bearing region (Ilupin et al., 1990; Mitchell, 1995; Morgan, 1995; Kutinov and Chistova, 2016).

Second group includes: hexagonal quartz, feldspars, pyroxenes (black, green, dark-green, gray-green, brown-green), magnetite, hematite, ilmenite, galenite, pyrite, limonite, small magnetic spheres, mica, hydro-mica, chromite, leucoxene, zircon (Figure 18), rutile, secondary minerals of cuprum (green and blue), calcite, etc. These minerals combined with the minerals of first group are also suggestive of the diamond potential of this area.

Identified mineral coesite, according to Sobolev (2006) is an important signature of deep origin of investigated rocks. 


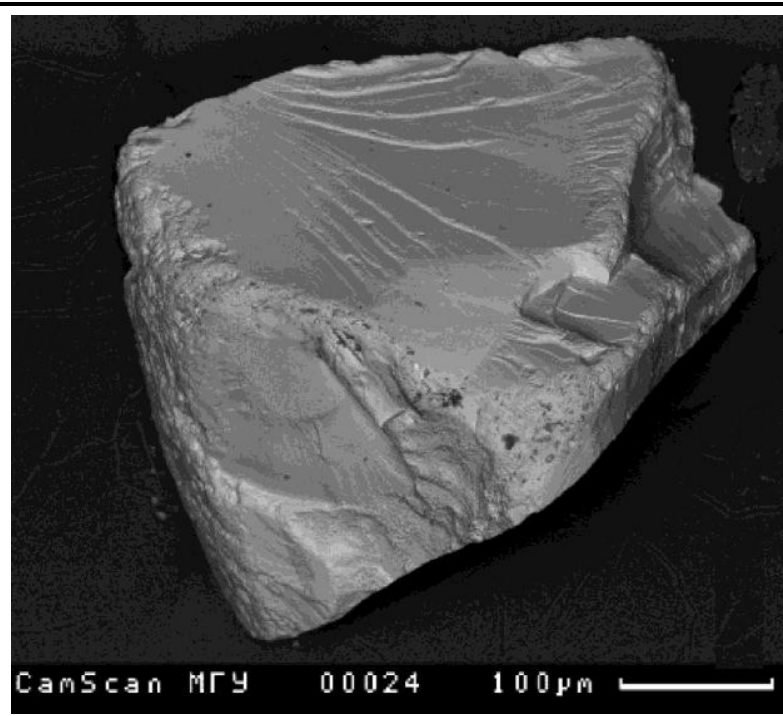

Figure 18. Zircon. Back-scattered electron image

An examination of rocks using fluoric and other acids led to discovering a number of gold and silver flakes accompanied by traces of REE: $\mathrm{La}, \mathrm{Ce}, \mathrm{Th}, \mathrm{Nb}$, and Ta. These elements can also be considered as indicators of the proximity of kimberlitic rocks (Kaminsky et al., 1974; Le Roex et al., 2003, Shcheka et al., 2006, Giuliani et al., 2013).

Identifed yttrium phosphate (Figure 19a and 19b) is usually associated with the nearest kimberlite occurring (Mitchell, 1986; Ilupin et al., 1990).

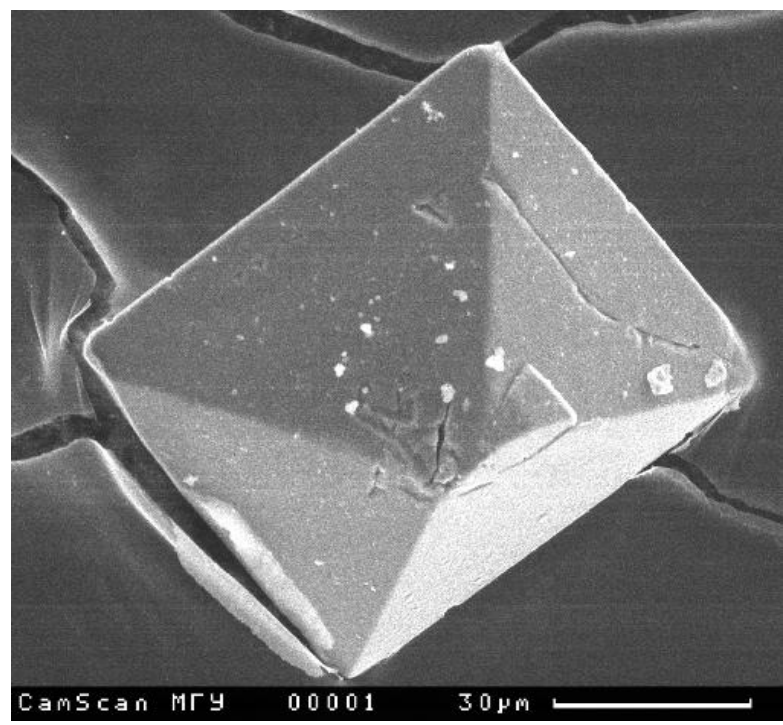

Figure 19a. Back-scattered image of yttrium phosphate crystal

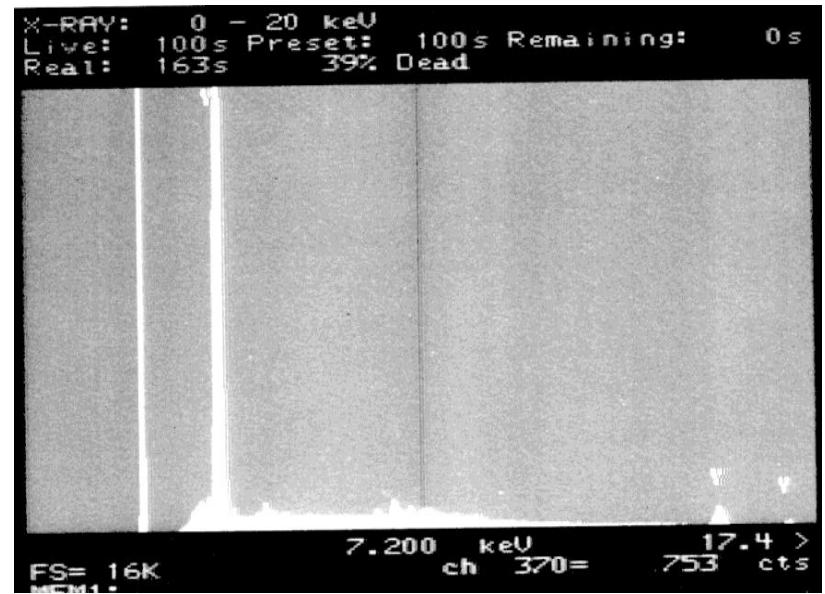

Figure 19b. Energy dispersion spectrum of the yttrium phosphate crystal 
Experimental testing of detrital sediments of the western Makhtesh Ramon enabled to found a set of minerals typical for arid climate, multiply re-deposited from the more ancient deposits and having rounded form: quartz, pyroxene, rutile, leucoxene, zircon and tourmaline. However, were found and minerals of a "fresh pattern" - not rounded and more stable in weathering conditions: green pyroxene, olivine, native silver, gypsum, calcite, barite and fieldspars. From the withdrawn samples a group of minerals having close size and weight of fragmental particles was selected (Table 1). At the same time, their densities are different. This fact indicates that conventional gravitational concentration in this area may be not effective (Samykina et al., 2005). Therefore, in Makhtesh Ramon area an enhanced scheme of mineral concentration (Surkov, 2000) was applied.

Table 1.Results of some minerals investigation in the western Makhtesh Ramon area, southern Israel (after Eppelbaum et al., 2002)

\begin{tabular}{|c|c|c|c|c|}
\hline $\mathrm{N} / \mathrm{n}$ & Mineral & Size, $\mathrm{mm}$ & $\begin{array}{c}\text { Average density, } \\
\mathrm{kg} / \mathrm{m}^{3}\end{array}$ & $\begin{array}{c}\text { Weight of crystal, } \\
\text { milligram }\end{array}$ \\
\hline 1 & Olivine & $1.36 \times 1.20 \times 0.72$ & 3500 & 4.11 \\
\hline 2 & Diopside & $1.34 \times 1.19 \times 0.79$ & 3300 & 4.15 \\
\hline 3 & Diamond & $1.35 \times 1.15 \times 0.75$ & 3510 & 4.09 \\
\hline 4 & Ilmenite & $1.36 \times 1.16 \times 0.55$ & 4750 & 4.13 \\
\hline 5 & Gold & $1.31 \times 0.90 \times 0.20$ & 1740 & 4.18 \\
\hline 6 & Quartz & $1.34 \times 1.17 \times 1.01$ & 2650 & 4.19 \\
\hline
\end{tabular}

Due to microscopic analysis has been selected and measured 1459 grains from 8 sites (the results reflect only preliminary stage of performed investigations), among which were identified pyrope, garnet, diopside, chromediopside, ilmenite, tourmaline, spinel, rutile, pyroxenes, zircon (Table 2) as well as galenite, pyrite, chalcopyrite, secondary minerals of cuprum, etc. (Eppelbaum et al., 2006). In probes selected from the deposits of temporary flows (alluvium) and conglomerates (Table 3), all the identified minerals were found in the secondary occurrence.

Table 2. Results of detailed granulometric analysis of monofractions of possible genetic and dynamic indicators of diamonds (density of diamond $\rho=3510 \mathrm{~kg} / \mathrm{m}^{3}$ )

\begin{tabular}{|c|c|c|c|c|c|c|c|c|c|c|}
\hline \multicolumn{2}{|c|}{$\rho, \mathrm{kg} / \mathrm{m}^{3}$} & 3580 & 3220 & 4750 & 3300 & 3270 & 3350 & 4210 & 4600 & $\Sigma$ \\
\hline № & $\begin{array}{c}\text { № of } \\
\text { sites }\end{array}$ & garnet & diopside & $\begin{array}{c}\text { picro- } \\
\text { ilmenite }\end{array}$ & spinel & $\begin{array}{c}\text { tourma- } \\
\text { line }\end{array}$ & $\begin{array}{c}\text { pyro- } \\
\text { xenes }\end{array}$ & rutile & zircon & \\
\hline 1 & S1 & - & - & 7 & - & 1 & - & 1 & - & $\mathbf{9}$ \\
\hline 2 & S2 Ш.1 & 13 & 12 & 58 & 9 & 80 & 13 & 6 & 23 & $\mathbf{2 1 4}$ \\
\hline 3 & S2 congl. & 11 & 24 & 59 & 4 & 75 & 55 & 169 & 95 & $\mathbf{4 9 2}$ \\
\hline 4 & S3 & 44 & 24 & 85 & - & 12 & 86 & 21 & 5 & $\mathbf{2 7 7}$ \\
\hline 5 & S3 & - & 2 & 5 & - & 23 & - & 59 & 14 & $\mathbf{1 0 3}$ \\
\hline 6 & S3 & 7 & 22 & 42 & 2 & 45 & 49 & 100 & 19 & $\mathbf{2 8 6}$ \\
\hline 7 & S4 & 2 & 2 & 10 & - & 17 & 10 & 12 & 1 & $\mathbf{5 4}$ \\
\hline 8 & S7 & 1 & 1 & 2 & - & 2 & - & 6 & - & $\mathbf{1 2}$ \\
\hline \multicolumn{2}{|c|}{$\sum$} & $\mathbf{7 8}$ & $\mathbf{8 7}$ & $\mathbf{2 6 8}$ & $\mathbf{1 5}$ & $\mathbf{2 4 5}$ & $\mathbf{2 1 3}$ & $\mathbf{3 7 4}$ & $\mathbf{1 5 7}$ & $\mathbf{1 4 4 7}$ \\
\hline
\end{tabular}

Total number of measurements: 4341

As it is noted in Table 3, many samples were collected in the dry channel ('wadi') of Nahal Ramon (Figure 20).

Table 3. Description of the selected samples (western Makhtesh Ramon)

\begin{tabular}{|c|c|c|c|c|}
\hline $\begin{array}{c}\text { No. of } \\
\text { sample }\end{array}$ & $\begin{array}{c}\text { Volume, } \\
\mathrm{m}^{3}\end{array}$ & $\begin{array}{c}\text { Weight, } \\
\mathrm{kg}\end{array}$ & $\begin{array}{c}\text { Weight of } \\
\text { concentrate, } \mathrm{kg}\end{array}$ & Notes \\
\hline S1 & 0.0025 & 7 & 0.3 & $\begin{array}{c}\text { Selected from small bore pit }(0.3 \mathrm{~m}) \text { in dry } \\
\text { channel (Nahal Ramon) }\end{array}$ \\
\hline S2 & 0.03 & 60 & 3.0 & $\begin{array}{c}\text { Cut out from the exposed conglomerates } \\
\text { and crushed in mortar till obtaining grain sizes } \\
\text { of 1 mm }\end{array}$ \\
\hline S2.Ш1 & 0.1 & 50 & 4.0 & $\begin{array}{c}\text { Selected from small bore pit with dimension of } \\
0.6 \times 0.6 \times 0.6 \mathrm{~m} \text { in dry channel with removing } \\
\text { fraction less than 1.6 mm }\end{array}$ \\
\hline S3 & 1.5 & 2000 & 10.0 & $\begin{array}{c}\text { Composed from four bore pits located at } \\
\text { distance } 30 \mathrm{~m} \text { between themselves in the }\end{array}$ \\
\hline
\end{tabular}


Lev V. Eppelbaum \& Vladimir L. Vaksman

\begin{tabular}{|c|c|c|c|c|}
\hline \hline S4 & 0.02 & 50 & 2.0 & $\begin{array}{c}\text { channel of dry rivulet with removing fraction less than } \\
1.6 \mathrm{~mm}\end{array}$ \\
\hline S7 & 0.04 & 70 & 2.0 & $\begin{array}{c}\text { Cut out from the output of indigenous rocks } \\
\text { with the following crushing and removing } \\
\text { fraction less than 1.6 mm (tuff breccia) }\end{array}$ \\
\hline
\end{tabular}

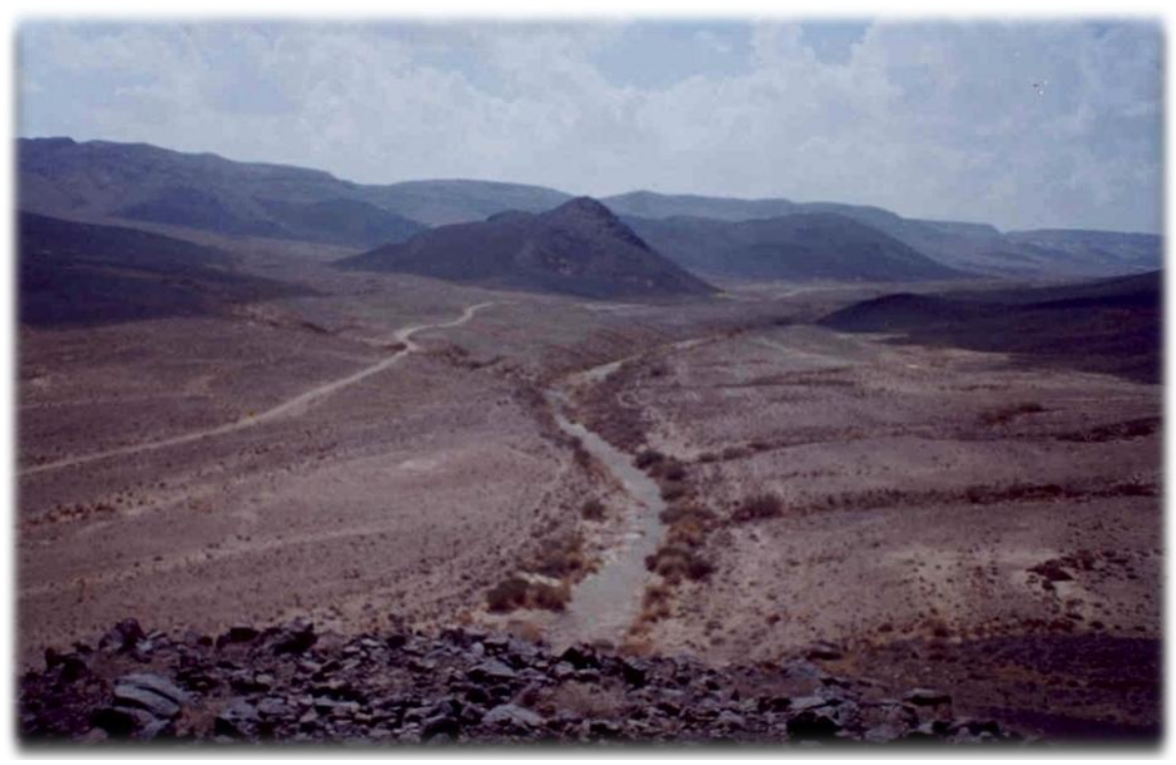

Figure 20. Valley of temporary channel ("wadi") Nahal-Ramon

We should underline the fact that minerals revealed in the possible diamondiferous association: pyrope, garnet, diopside, chromediopside, picroilmenite, ilmenite and spinel (according to the investigations carried out by useof optical microscope $M B S-10$ ) have no traces of wear (they are not smoothed) that indicates the indigenous sources occurring. All the prerequisites to presence of the desired diamondiferous associations (volcanism, structural-tectonic environments, geomorphological conditions) have been observed and examined (Eppelbaum et al., 2002, 2003, 2006). The most representative minerals-indicators were studied by use of the electronic scanning microscope JSM5300 where were obtained their images in reflected electrons and energy dispersion spectrums reflecting their chemical composition. Altogether about 100 minerals by the use of afore-mentioned methodology have been studied (preliminary stage).

A short description of the discovered main minerals-indicators of diamonds is presented below.

Picroilmenite is a well-known high-pressure mineral of kimberlites (Haggerty, 1995; Nixon, 1995; Kharkiv, 1997). Elements composed the mineral grating are presented by titan, ferrum and oxygen. As admixtures, $\mathrm{Mg}, \mathrm{Al}$ and $\mathrm{Cr}$ (it is possible that the elements are involved to microphases), and calcium (from calcite), were detected. Detected phase 'calcium-titan' from perovskite is also well known in kimberlites (Haggerty, 1995; McClenahgan et al., 2000; Nixon, 1995). Such revealed admixtures as cobalt, nickel and natural ferrum (reflecting to the ultrabasic consistency of magma) are also typical for kimberlites. Manganese reflects the exogenetic hydroxides and carbon - raise dusting for increasing of conductivity. Thus, the observed crystals of picroilmenite correspond to known (Cullers et al., 1996; Griffin and Ryan, 1995; Mitchell, 1986, 1995) indicators of diamondiferous associations. From the electronic imaging follows that the studied grains have a complex structure. It should be noted that their micro-aggregates are similar to nodules (micro-nodules) without drastic transportation from the indigenous source (the crystal surface is not rolled).

Pyrope is one of the most important minerals-indicators of diamond association (both for kimberlites and lamproites) (Mitchell, 1986; Nixon, 1995; Kharkiv et al., 1997). Studied grains have characterized by light crimson and red color with lilac tint. The surface of crystals is not rolled. Electronic microscope examination indicates that among the main elements are magnesium (magnesia pyrope), aluminum, silicium and oxygen that confirm the visual diagnostics of mineral type. Admixtures of chrome and magnesium in pyrope unambiguously designate that the mineral was 
originated under high pressures (large depths). Calcium, obviously, reflects the calcite micro-phases and carbon - raise dusting.

Pyroxenes were detected in the various probes selected in the area (from 3-5 up to 15 units of this mineral) (see Table 2). Color of pyroxenes is dark-green, brown, and sometimes black. These minerals are also not eroded. Pyroxenes are essential components of kimberlites together with the products of alterations of ultrabasic and basic rocks. The majority of the known diamondiferous associations contain these minerals (Bulanova, 1995; McClenahgan et al., 2000; Kharkiv et al., 1997).

Chromediopside is the well-known mineral involving to the diamond association (Mitchell, 1986,1995; McClenahgan et al., 2000; Nixon, 1995). An important pecularity of this mineral is that it is not stable by alluvial transportation and hypergene weathering (Marshall and Baxter-Brown, 1995; Mitchell, 1995; Kharkiv et al., 1997). This mineral is the generic isomophic type of diopsidehedenbergite (Mitchell, 1995). In diopside the main elements are calcium, magnesium, cilisium and oxygen. Chrome admixture riches $7 \%$ and $\mathrm{MgO}-18 \%$. Color of the studied samples of chromediopside is some lighter than the typical chromediopside grains. Admixture of titanium is typical for such titanium varieties of ultra basic rocks as kimberlites and lamproites. The mineral is practically not eroded that indicates nearest occurrence of endogenic rocks.

Technological scheme of diamond recognition from the withdrawn concentrate is presented in Figure 21. Besides the conventional procedures (ranging of grains by size, magnetic sepration, visual identification. X-ray luminescence, electronic microscopy, etc.) some concentrated solutions were employed. Application of these solutions $\left(3 \mathrm{HCL}+\mathrm{HNO}_{3}, \mathrm{HF}\right)$ accompanied by boiling was caused by the fact that many desired minerals were re-deposited several times in the conditions of exremally arid climate of southern Israel (e.g., Bentor, 1969) and were covered by some hard shells. Removing these shells was impossible without employment of these solutions (Eppelbaum et al., 2002). This explains, besides all, why diamonds were not found earlier in the area (excluding Flexer et al., 1988b). Applying the mentioned technological scheme a final stage allowed to discover at numerous microdiamonds and several diamonds.

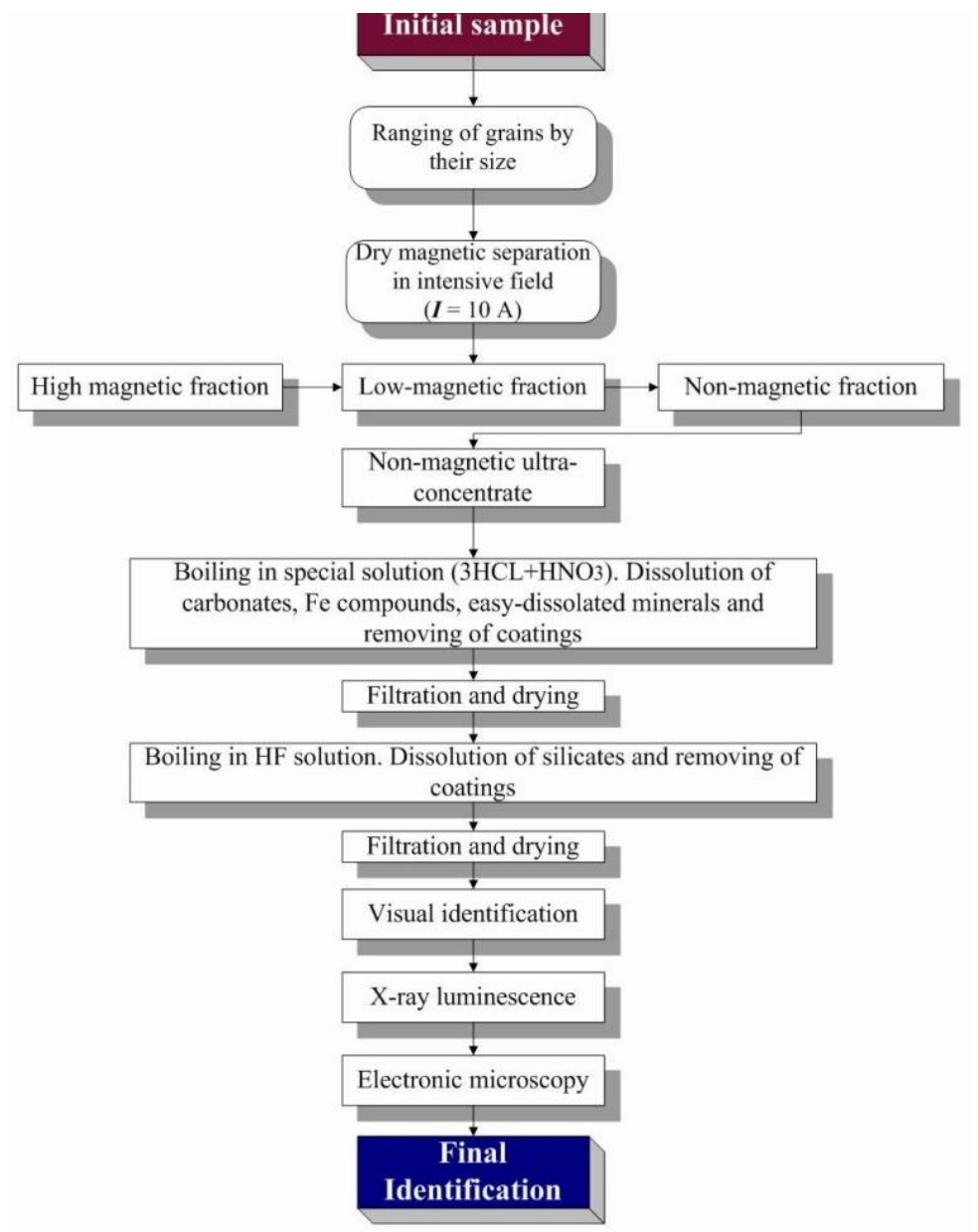

Figure 21. Fractionation of selected samples of titanomagnetite association: A technological scheme 
After conducting visual and qualitative/quantitative analyses by the use of a binocular microscope, the polymineral fractions were investigated using a Camscan-DV scanning electron microscope equipped with an energy-dispersive Link AN10000 microprobe. The most significant result of these studies was the discovery of more than 300 microdiamonds $(<1 \mathrm{~mm}$ and $<<1 \mathrm{~mm}$ ) and five diamonds ranging in size from 1 to $1.35 \mathrm{~mm}$. Most of them were characterized by a cubic habit, and hexagonal species were less. Figure 22 shows microdiamond associated with a quartz. Two large discovered diamond crystals (which are fragments of a larger crystal (Surkov et al., 2008)) measured 1.35 mm (Figure 23) and $1.20 \mathrm{~mm}$.

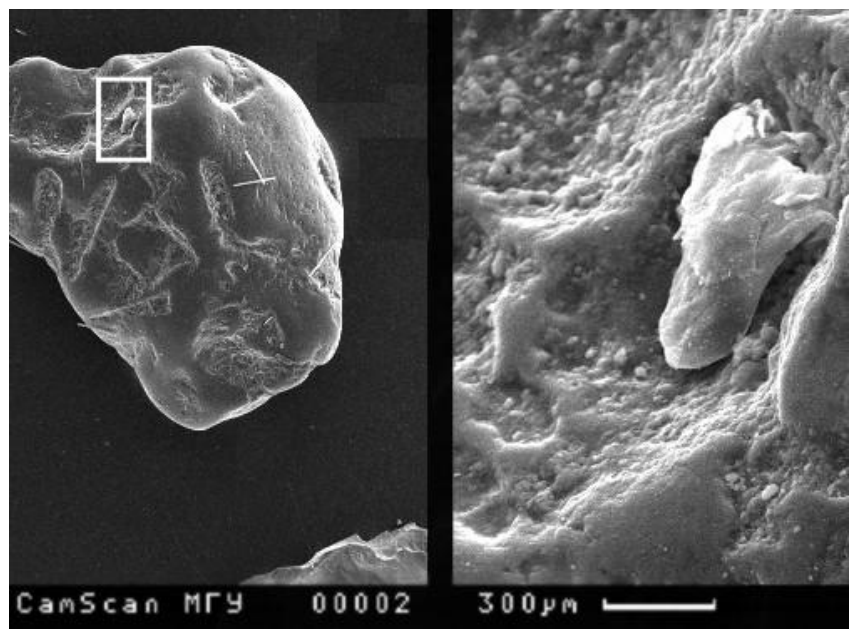

Figure 22. Left: quartz, with diamond, Right: increased image of diamond. Back-scattered electron images
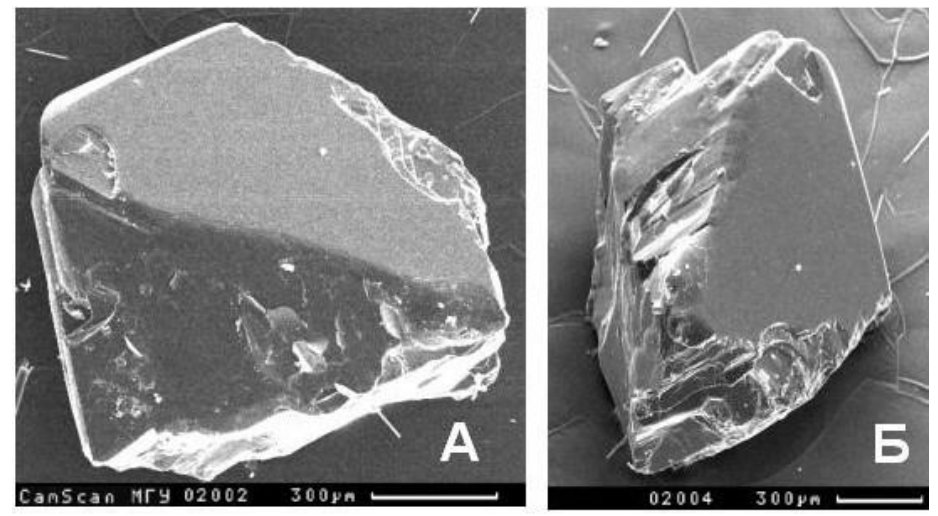

Figure 23. The largest diamond crystal ever identified ( $A$ and 5 are the back-scattered electron images of the same crystal from different sides)

Identified sample of meimechite rock, chemical composition of which is very similar to kimberlite associations (e.g., Arndt et al., 1995), is shown in Figure 24 (Eppelbaum et al., 2003).

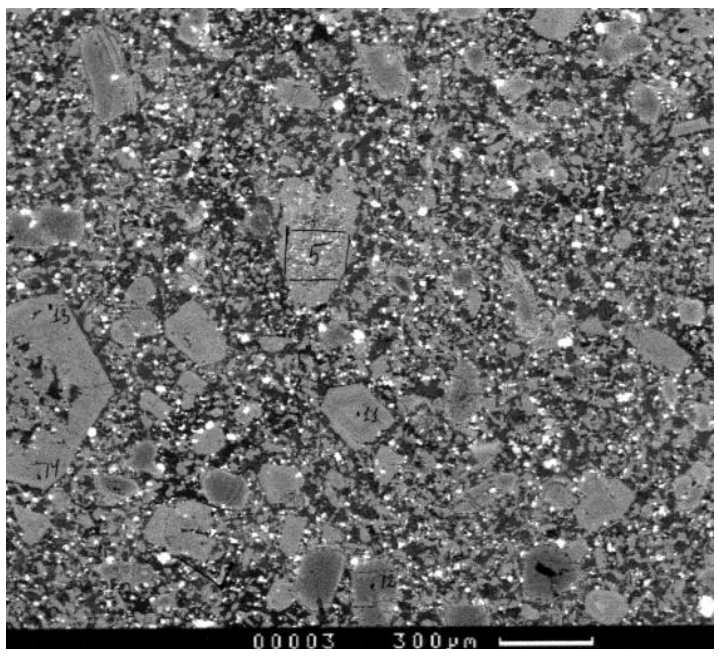

Figure 24. Sample of meimechite rock. Back-scattered electron image 
In the western part of the Makhtesh Ramon Canyon exposed volcanic and volcanic-fragmentary rocks were studied. These outcrops represent hills with the height up to $150 \mathrm{~m}$, and are, from the geological point of view, relics of volcanic flows (Bentor, 1952), for which often is typical columnar (prismatic) individuality. Sometimes these flows break by small subvolcanic bodies. For some outcrops is typical presence of volcanogenic-fragmental rocks. Magmatic rocks sometimes covered by deposits of Lower Cretaceous that determines upper limit of the area magmatic activity; at the same time rocks older that Lower Triassic are broken by these rocks. Thus, by geological data, all magmatic activity had a place in the interval of Lower Trias - Upper Cretaceous (Bentor, 1952). A time of the magmatic rocks generation was determined using isotope K-Ar dating - about 125-115 Ma (Lang and Steinitz, 1985, 1989; Lang et al., 1988; Recanti et al., 1989).

About 100 bright transparent sections was studied using polarized microscope, electronic microscope Camscan 4DV and energy-dispersion micro-probe analyzer Link-10000. The effusive rocks were divided by their composition on: (1) plagioclase-containing and (2) no containing plagioclase.

The main volume of samples, withdrawn at the point 100 (probes 100-15;100-15A; 100-16) (Figure 25 ) and the points 124 and 125, consists of olivine, clinopyroxene, titanomagnetite and nepheline, and glass. Sometimes albite and potassic feldspars were recognized. A content of nepheline reaches 5$10 \%$.
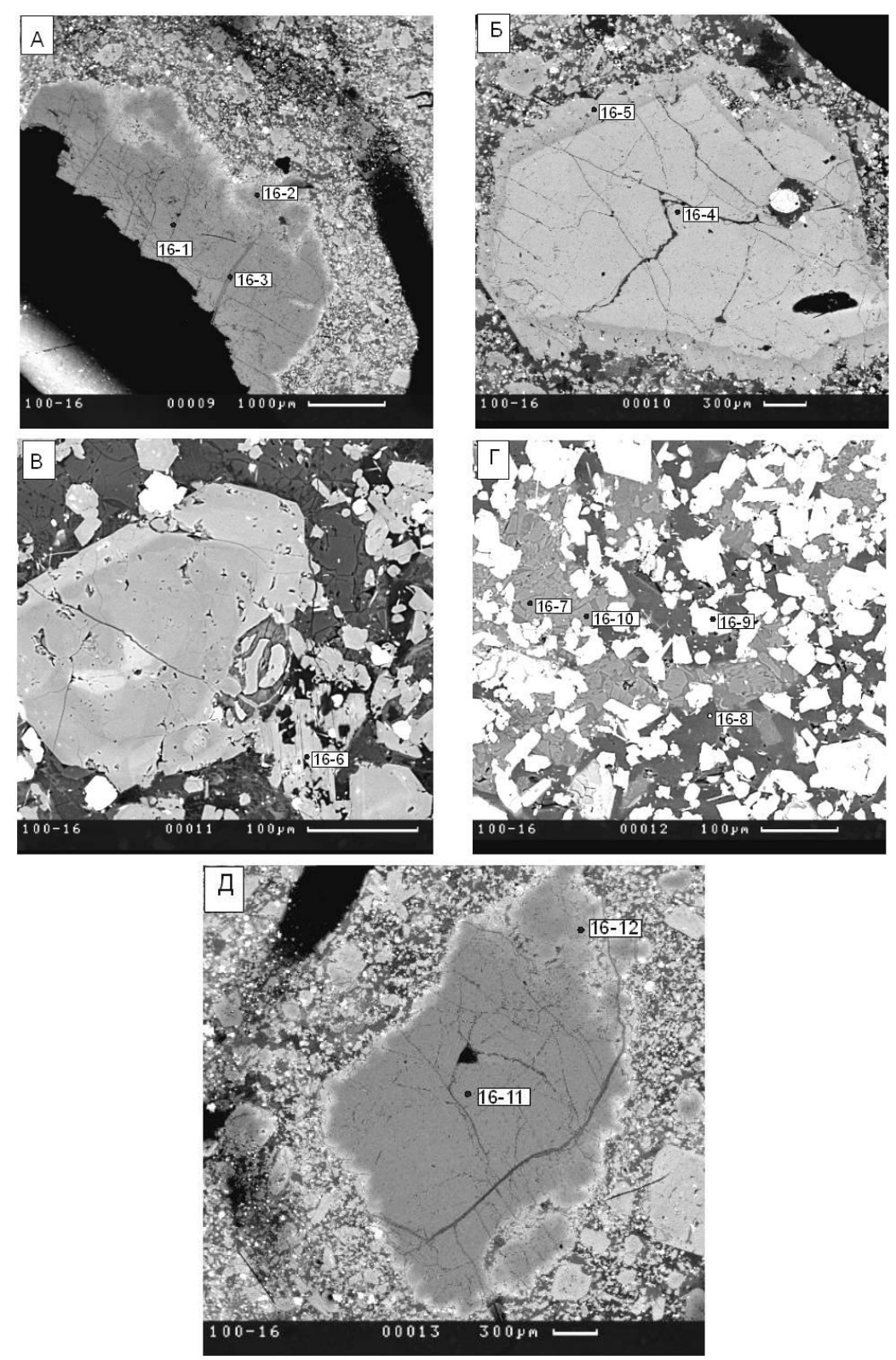

Figure 25. Samples withdrawn in probe № 100_16 in Makhtesh Ramon. $\boldsymbol{A}$ and Д - olivine of I and IV generations, $\boldsymbol{\Gamma}$ and $\boldsymbol{B}$ - clinopyroxenes, $\boldsymbol{\Gamma}$ - main mass presented by nepheline points 16-7 and 16-10), titanomagnetite (point 16-9) and glass (point 16-8) 
Contains of $\mathrm{Cr}_{2} \mathrm{O}_{3}$ in clinopyroxenes from the sedimentary deposits of Makhtesh Ramon range in limits of $0.5-1.2 \%$ (Table 4; here only part of measurements is presented); contents of $\mathrm{FeO}$ changes from 2.5 up to $6 \%$ that is typical for chrome diopsides and kimberlites and other associations (deep inclusions, basalts and carbonates) (Ilupin, 1984). Content of $\mathrm{Al}_{2} \mathrm{O}_{3}$ in the studied clinopyroxenes changes from 2.3 to $6.6 \%$, and $\mathrm{Na}_{2} \mathrm{O}$ - from 0.5 to $1.5 \%$ (Table 4). In the diagram of $\mathrm{Al}_{2} \mathrm{O}_{3}-\mathrm{Na}_{2} \mathrm{O}$ composition of studied clinopyroxenes (according to Ilupin (1984) classification) hit in the domain of chromediopsides of deep inclusions in basalts and kimberlites of northern America. Comparison of the studied clinopyroxenes (western Makhtesh Ramon) with the chromediopsides from kimberlites of the "Arkhangelskaya" pipe (Winter Coast, Siberia, Russia) (Kharkiv et al., 1995) indicates that chromdiopsides of sedimentary deposits of Makhtesh Ramon are similar to low-baric group of clinopyroxenes generated from the disintegrated spinel peridodites propagating by magmatic melts from the upper mantle (spinel peridodites are a composite part of the deep spinel-pyroxene phase). Comparison of the chromediopsides from sedimentary deposits of Makhtesh Ramon (Eppelbaum et al., 2003) with the clinopyroxenes of Zolotnitsky field of the Arkhangelsk province (Bogatikov, 1999) points out their closeness to clinopyroxenes of diamondiferous lherzolites and websterites. Thus, chromediopsides of Makhtesh Ramon are located in the domain of high-alumna and low-sodium inclusions in the diagrams of various authors. Source of these inclusions may be deep xenoliths of basalts (Ilupin, 1984), encountered in kimberlite pipes in form of fragments of spinel peridotites (Kharkiv et al., 1995), peridotites and pyroxenes (Bogatikov, 1999).

Table 4. Composition of chrome clinopyroxenes (chromediopsides) from the sedimentary deposits of the western Makhtesh Ramon

\begin{tabular}{|c|c|c|c|c|c|c|c|c|c|c|c|}
\hline & $\begin{array}{l}100 / \\
1 \_50\end{array}$ & $\begin{array}{l}100 / \\
1 \_20\end{array}$ & $\begin{array}{l}100 / \\
1 \_21\end{array}$ & $\begin{array}{l}100 / \\
1 \_27\end{array}$ & $\begin{array}{l}100 / \\
1 \_28\end{array}$ & $\begin{array}{l}100 / \\
1 \_29\end{array}$ & $\begin{array}{l}100 / \\
1 \_30\end{array}$ & $\begin{array}{l}100 / \\
1 \_31\end{array}$ & $\begin{array}{l}100 / \\
1 \_32\end{array}$ & $\begin{array}{l}100 / \\
1 \_34\end{array}$ & $\begin{array}{l}100 / \\
1 \_35\end{array}$ \\
\hline $\mathrm{SiO}_{2}$ & 52.68 & 51.32 & 50.81 & 53.25 & 52.67 & 52.61 & 52.22 & 53.36 & 53.16 & 53.02 & 50.19 \\
\hline $\mathrm{TiO}_{2}$ & 0.36 & 0.62 & 0.54 & 0.00 & 0.00 & 0.32 & 0.29 & 0.00 & 0.24 & 0.25 & 1.25 \\
\hline $\mathrm{Al}_{2} \mathrm{O}_{3}$ & 2.81 & 5.38 & 5.64 & 4.81 & 5.01 & 5.28 & 5.84 & 4.21 & 4.28 & 2.32 & 4.38 \\
\hline $\mathrm{FeO}$ & 4.70 & 4.35 & 4.44 & 2.67 & 2.69 & 3.01 & 2.78 & 2.77 & 2.99 & 3.05 & 4.55 \\
\hline $\mathrm{MnO}$ & 0.25 & 0.25 & 0.00 & 0.00 & 0.00 & 0.00 & 0.00 & 0.00 & 0.00 & 0.00 & 0.00 \\
\hline $\mathrm{MgO}$ & 15.55 & 16.00 & 16.35 & 15.71 & 15.97 & 15.77 & 15.65 & 16.26 & 16.13 & 17.24 & 14.26 \\
\hline $\mathrm{CaO}$ & 22.49 & 20.33 & 20.19 & 21.61 & 21.63 & 20.70 & 20.97 & 21.59 & 21.70 & 22.13 & 23.83 \\
\hline $\mathrm{Na}_{2} \mathrm{O}$ & 0.56 & 0.77 & 0.82 & 1.17 & 1.18 & 1.39 & 1.13 & 0.98 & 0.78 & 0.98 & 0.39 \\
\hline $\mathrm{K}_{2} \mathrm{O}$ & 0.00 & 0.00 & 0.00 & 0.00 & 0.00 & 0.00 & 0.00 & 0.00 & 0.00 & 0.00 & 0.00 \\
\hline $\mathrm{Cr}_{2} \mathrm{O}_{3}$ & 0.62 & 0.98 & 1.22 & 0.77 & 0.85 & 0.93 & 1.13 & 0.82 & 0.73 & 1.00 & 1.14 \\
\hline \multirow[t]{2}{*}{$\mathrm{NiO}$} & 0.00 & 0.00 & 0.00 & 0.00 & 0.00 & 0.00 & 0.00 & 0.00 & 0.00 & 0.00 & 0.00 \\
\hline & $114 / 2 \_3$ & 114/ 2_66 & 114/2_67 & $114 / 2 \_68$ & $114 / 2 \_69$ & $114 / 2 \_70$ & $\begin{array}{l}114 / \\
2 \_71 \\
\end{array}$ & $\begin{array}{l}114 / \\
2 \_72 \\
\end{array}$ & $\begin{array}{l}114 / \\
2 \_74 \\
\end{array}$ & $\begin{array}{l}114 / \\
2 \_75 \\
\end{array}$ & $\begin{array}{l}114 / \\
2 \_76\end{array}$ \\
\hline $\mathrm{SiO}_{2}$ & 52.34 & 52.77 & 47.55 & 52.83 & 52.84 & 52.91 & 52.43 & 52.33 & 52.20 & 52.83 & 47.69 \\
\hline $\mathrm{TiO}_{2}$ & 0.38 & 0.42 & 1.77 & 0.21 & 0.00 & 0.00 & 0.25 & 0.25 & 0.32 & 0.29 & 1.88 \\
\hline $\mathrm{Al}_{2} \mathrm{O}_{3}$ & 5.22 & 2.95 & 6.59 & 5.55 & 5.26 & 4.99 & 4.90 & 5.31 & 5.56 & 5.01 & 6.20 \\
\hline $\mathrm{FeO}$ & 2.98 & 4.74 & 6.03 & 3.18 & 2.79 & 2.94 & 2.67 & 2.98 & 3.20 & 2.76 & 5.97 \\
\hline $\mathrm{MnO}$ & 0.00 & 0.22 & 0.00 & 0.00 & 0.00 & 0.00 & 0.00 & 0.00 & 0.00 & 0.00 & 0.00 \\
\hline $\mathrm{MgO}$ & 15.96 & 14.68 & 12.90 & 15.26 & 14.92 & 15.55 & 15.97 & 15.82 & 15.13 & 15.70 & 13.06 \\
\hline $\mathrm{CaO}$ & 20.91 & 22.94 & 23.64 & 20.78 & 22.40 & 20.58 & 20.97 & 21.06 & 20.79 & 21.29 & 24.05 \\
\hline $\mathrm{Na}_{2} \mathrm{O}$ & 0.92 & 0.83 & 0.60 & 1.35 & 1.11 & 1.71 & 1.42 & 1.29 & 1.66 & 1.12 & 0.50 \\
\hline $\mathrm{K}_{2} \mathrm{O}$ & 0.00 & 0.00 & 0.00 & 0.00 & 0.00 & 0.00 & 0.00 & 0.00 & 0.00 & 0.00 & 0.00 \\
\hline $\mathrm{Cr}_{2} \mathrm{O}_{3}$ & 1.01 & 0.46 & 0.90 & 0.85 & 0.68 & 1.34 & 1.39 & 0.94 & 1.14 & 0.99 & 0.65 \\
\hline $\mathrm{NiO}$ & 0.00 & 0.00 & 0.00 & 0.00 & 0.00 & 0.00 & 0.00 & 0.00 & 0.00 & 0.00 & 0.00 \\
\hline
\end{tabular}

Comprehensive mineralogical and geochemical analyses enabled to detect several native small gold plates (Eppelbaum et al., 2003, 2006). The identified gold plates were investigated using Surkov's (2000) advanced methodology (Figure 26). It should be noted that heightened concentration of gold and Rare Earth Elements (REE) in Makhtesh Ramon sediments was identified earlier by Lavi et al. (1988). Flexer et al. (1988a) and Rosenfeld et al. (1989) have reported about detecting some platinumgroup elements in the vicinity of Makhtesh Ramon area. Besides this, Adatte et al. (2005) found Platinum Group Elements in trace quantities in another member of makhteshim family - Makhtesh Gadol. 


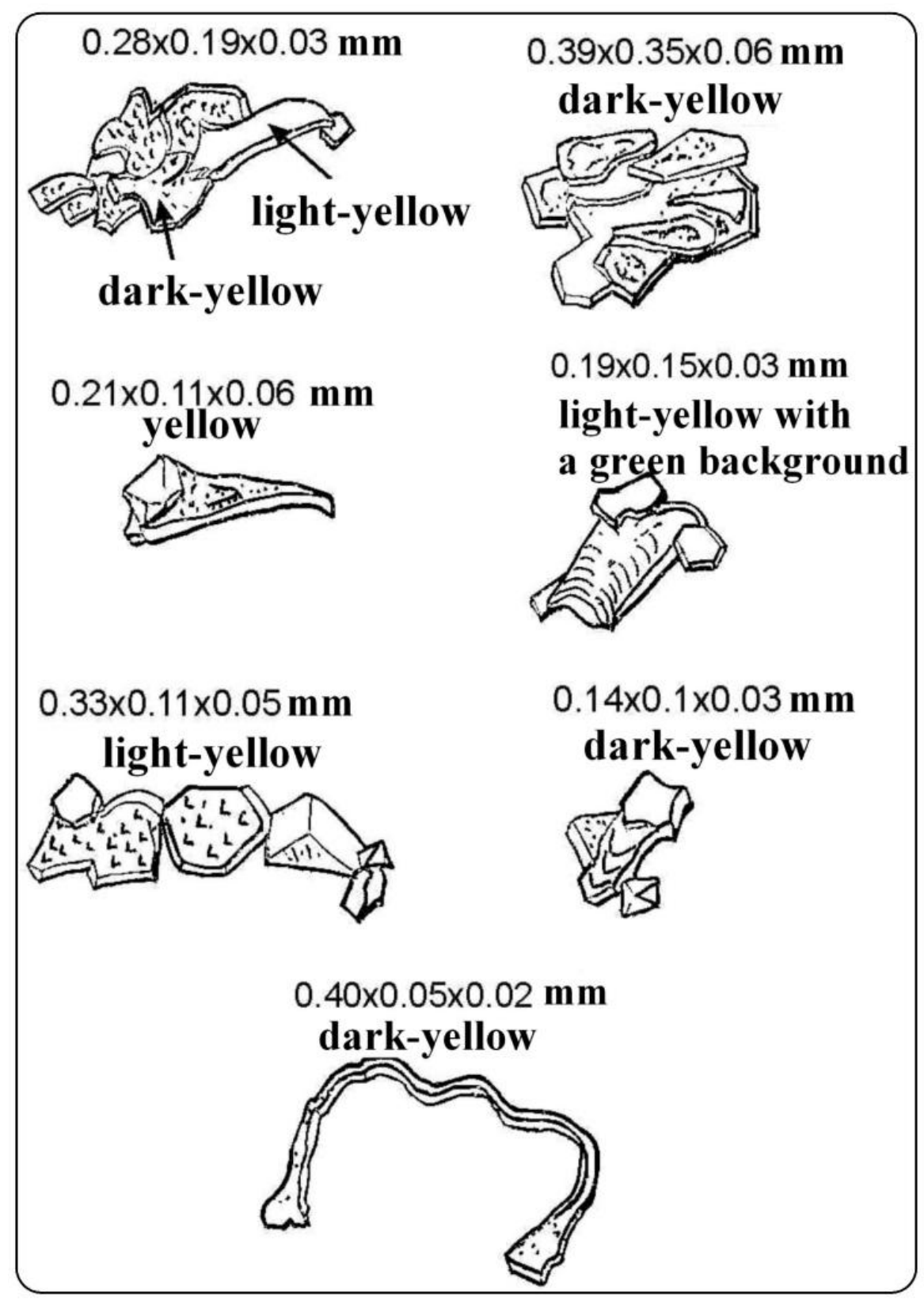

Figure 26. Forms of native gold plates discovered in the channel deposits of Nahal Ramon in the western Makhtesh Ramon

Presence of gold and platinum-group elements may also testify (Kaminsky et al., 1974; McDonald et al., 1995; Paul et al., 1979) the nearest occurring of basic kimberlite pipes. At the same, presence of gold, platinum and REE may have an independent importance. We propose that Makhtesh Ramon window to Earth's upper mantle - contain a complex ore deposit.

\section{DiscuSSION AND CONCLUSIONS}

Maximum number of kimberlite pipes has been formed in the world (by radiometric data) is in the interval of 125-63.5 Ma (Katz and Eppelbaum, 1998). It coincides with the maximal magmatic activation in the region under study $-120 \mathrm{Ma}$. All the afore-mentioned geophysical, tectonic, mineralogical, petrological, geochemical and some other factors described in the previous sections indicate to presence of rocks of abyssal origin (uncluding diamondferous and other economic components) in the Makhtesh Ramon area.

Analyzing Makhtesh Ramon complex deposit (Eppelbaum et al., 2006) together with discovering diamonds and kimberlite indicator minerals in Qishon Valley (northern Israel) (Eskel et al., 2007) and NW Syria (Mahfoud, 2002) resulted in a map showing the East Mediterranean-Nubian diamondiferous belt (Eppelbaum and Katz, 2012) (Figure 27). 


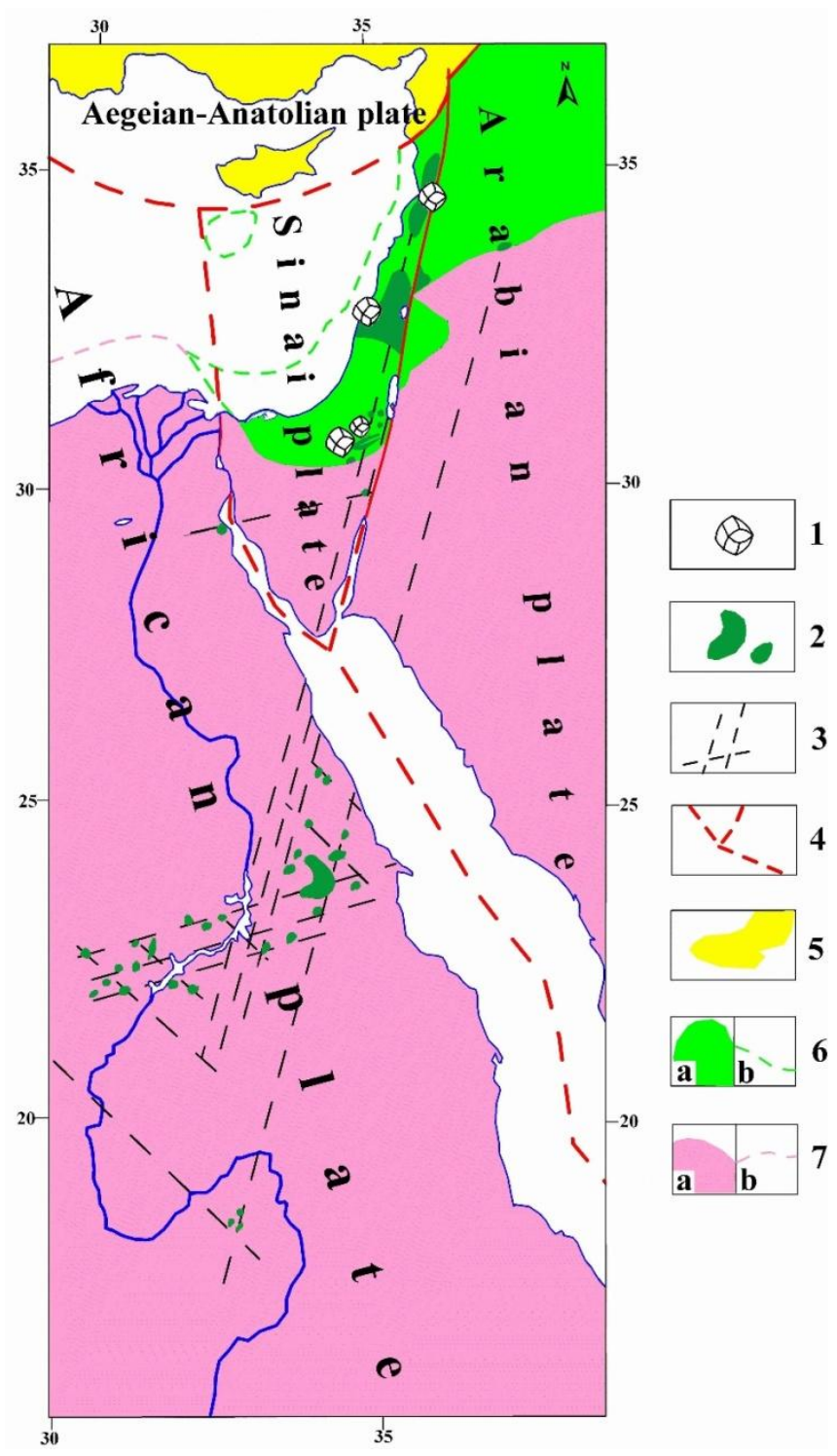

Figure 27. East Mediterranean-African (Nubian) diamondiferous belt

(1) areas of diamond discovery, (2) Cretaceous magmatics, (3) Levantine-Nubian volcanic fault system, (4) boundaries between the tectonic plates, (5) Aegean-Anatolian plate, (6) province of terrane belt with a thinned Precambrian crust ( $a$-land, $b$ - marine), (7) province located on the ancient Nubian-Arabian Precambrian platform ( $a$-land, $b$ - marine)

The available numerous geological and geophysical data designate that the Makhtesh Ramon area (southern Israel) is favorable for the discovery of a diamondiferous deposit (Eppelbaum et al., 2003, 2006). Judging from the petrographic, geophysical, and geomorphological data, the diamondiferous sources are situated at shallow depths (Eppelbaum et al., 2002). Unfortunately, further investigations of the Makhtesh Ramon area are hampered by the fact that this area is a state geological reserve, where all mining is prohibited. It is likely however that further combined mineralogical, geochemical, and geophysical studies, integrated with mining works, will be rewarded with the discovery of diamondiferous rocks and other useful minerals. Presence here such useful components as gold and Rare Earth Elements (especially last ones) may have no important significance than diamonds. Undoubtedly, this area may be a center of mining exploration in Israel (country characterized by the most advanced in world diamond-manufacturing industry).

Analysis of the tectonic evolution model testifies that essential erosion processes strongly reduced thickness of sedimentary deposits in the studied area. It permits to perform an essential part of mining works by the most inexpensive open-cut method. Revealed horizons of technical water of superficial occurrence (e.g., Issar, 1983; Ben-David et al., 2002) is crucial for the process of withdrawn samples enrichment. Soft climate allows to carry out integrated mining-geological works the whole year round by minimization of energetic expenditures. Another important factor is the lack of jobs in the closely- 
located towns and settlements (creation of a mining center may provide several hundreds of new working places). Finally, the projected water channel between the Red and Dead seas (Abu Ghazleh et al., 2009; Jall, 2016) is located near the discovered deposit that will allow to connect up additional communicational (including the channel and railway) and electric (hydroelectric power station) capacities.

A very simplified calculation may be carried out using elementary principles of the probability theory. Generally speaking, we have six independent indicators (regional tectonics, regional geophysics, local geophysics, mineralogy, petrology and geochemistry) positively estimating the diamond-bearing of the Makhtesh Ramon area. Let's consider for simplicity these indicators as equivalent between themselves and $=1 / 2$. Actually, significance of mineralogical indicator (revealing of diamonds and indicator minerals) is greatly high than $1 / 2$. The probability of the random coincidence of these factors (according to the trivial rules of the probability theory (e.g., Koralov and Sinai, 2007)) in this case is $(1 / 2)^{6}=0.0156=1.56 \%$, e.g. positive assessment of the diamond-bearing of Makhtesh Ramon area is $98.44 \%$. Really this parameter is more high.

\section{REFERENCES}

[1] Abu Ghazleh, S., Hartmann, J., Jansen, N. and Kempe, S., 2009. Water input requirements of the rapidly shrinking Dead Sea. The Science of Nature (Springer), doi: 10.1007/s00114-009-0514-0.

[2] Adatte, T., Keller, G., Stuben, D., Harting, M., Kramar, U., Stinnesbeck, W., Abramovich, S. and Benjamini, C., 2005. Late Maastrichtian and K/T paleoenvironment of the eastern Tethys (Israel): mineralogy, trace and platinum group elements, biostratigraphy and faunal turnovers. Bull. Soc. Geol. Fr., 176, No 1, 37-55.

[3] Ahrens, L.H., Dawson, J.B., Duncan, A.R. and Erlank, A.J. (Eds.), 1975. Selected Papers presented at the 1st Intern. Conf. on Kimberlites (Cape Town, 1973). Physics and Chemistry of the Earth, IX, Pergamon Press.

[4] Arndt, N., Lehnert, K. and Vasil'ev, Y., 1995. Meimechites: highly magnesian lithospherecontaminated alkaline magmas from deep subcontinental mantle. Lithos, 34, No. 1-3, 41-59.

[5] Avni, Y., 2001. Structure and landscape evolution of the Makhteshim Country - interrelations between monoclines, truncation surfaces and the evolution of the Makhteshim. In: (Krasnov, B. and Mazor, E., Eds.) The Makhteshim Country: A Laboratory of Nature. Pensoft, Bulgaria, 3358.

[6] Baer, G., 1993. Flow directions in sills and dikes and formation of cauldrons in eastern Makhtesh Ramon. Israel Jour. of Earth Sci., 42, 133-148.

[7] Baer, G., Heimann, A., Eshet, Y., Weinberger, R., Mussett, A. and Sherwood, G., 1995. The Saharonim Basalt: A Late Triassic - Early Jurassic intrusion in southeastern Makhtesh Ramon, Israel. Israel Jour. of Earth Sci., 44, 1-10.

[8] Baer, G. and Reches, Z., 1991. Mechanics of emplacement and tectonic implications of the Ramon dike systems, Israel. Jour. of Geophysical Research, 96(B7), 11895-11910.

[9] Benjamini, C., 1980. The geological history of central and southern Israel during the Eocene. Ph.D. Thesis, Hebrew Univ., Jerusalem.

[10] Bentor, Y.K., 1952. Magmatic intrusions and lava sheets in the Ramon area in the Negev (southern Israel). Geol. Mag., 89, 129-140.

[11] Bentor, Y.K., 1969. On the evolution of subsurface brines in Israel. Chemical Geology, 4, 83110.

[12] Bentor, Y.K., Vroman, A. and Zak, I., 1965. The geological map of Israel, scale 1:250,000, southern sheet. Geol. Surv. Israel.

[13] Ben-Avraham, Z. and Ginzburg, A., 1990. Displaced terranes and crustal evolution of the Levant and the eastern Mediterranean. Tectonics, 9, 613-622.

[14] Ben-Avraham, Z., Ginzburg, A., Makris, J. and Eppelbaum, L., 2002. Crustal structure of the Levant basin, Eastern Mediterranean. Tectonophysics, 346, 23-43.

[15] Ben-David, R., Eyal., Y., Zilberman, E. and Bowman, D., 2002. Fluvial systems response to rift margin tectonics: Makhtesh Ramon area, southern Israel. Geomorphology, 45, 147-163. 
[16] Ben-David, R. and Mazor, E., 1988. Stages in the evolution of Makhtesh Ramon and its drainage system. Israel Jour. of Earth Sci., 37, 125-135.

[17] Bobrievich, A.P., Bondarenko, M.N., Gnevushev, M.A., Smirnov, G.I. and Yurkevich, R.K., 1959. Diamond Deposits of Yakutia. Gosnauchtekhizdat, Moscow (in Russian).

[18] Bogatikov, O.A. (Ed.), 1999. Arkhangelsk Diamondiferous Province (Geology, Petrography, Geochemistry and Mineralogy). Moscow State Univ., Moscow (in Russian).

[19] Bulanova, G.P., 1995. The formation of diamond. Jour. of Geochem. Exploration, 53, 1-23.

[20] Chang, S.-J. and van der Lee, S., 2011. Mantle plumes and associated flow beneath Arabia and East Africa. Earth and Planetary Sci. Letters, 302, 448-454.

[21] Cherepanova,Y., Artemieva, I.M., Thybo, H. and Chemia, Z., 2013. Crustal structure of the Siberian craton and the West Siberian basin: Anappraisal of existing seismic data. Tectonophysics, 609, 154-183.

[22] Condie, K.C., 2001. Mantle Plumes and Their Record in Earth History. Cambridge Univ. Press, Cambridge.

[23] Cullers, R.L., Dorais, M.J., Berendsen, P. and Chaudhuri, S., 1996. Mineralogy and petrology of Cretaceous lamproite sills, southeastern Kansas, USA. Lithos, 38, 185-206.

[24] Eppelbaum, L.V. (Ed.), 2015. Introduction to New Developments in Paleomagnetism Research. Ser: Earth Sciences in the 21st Century. Nova Science Publisher, NY, vii-viii.

[25] Eppelbaum, L., Ben-Avraham, Z. and Katz, Y., 2005. Does mantle diapir produce Hebron magnetic anomaly? Trans. of the Conf. of the Israel Geol. Soc. Ann. Meet., Moshabim Country Logging (Negev), Israel, p. 26.

[26] Eppelbaum, L.V. and Katz, Y.I., 2012. Mineral deposits in Israel: A contemporary view, In: (Eds. Ya'ari, A. and Zahavi, E.D.) Israel: Social, Economic and Political Developments, Nova Science Publishers, N.Y., USA, 1-41.

[27] Eppelbaum, L.V. and Katz, Yu.I., 2015. Eastern Mediterranean: Combined geologicalgeophysical zonation and paleogeodynamics of the Mesozoic and Cenozoic structuralsedimentation stages. Marine and Petroleum Geology, 65, 198-216.

[28] Eppelbaum, L.V. and Khesin, B.E., 2012. Geophysical Studies in the Caucasus. Springer, Heidelberg-N.Y.

[29] Eppelbaum, L.V., Khesin, B.E., Itkis S.E. and Ben-Avraham, Z., 2004. Advanced analysis of self-potential data in ore deposits and archaeological sites. Proceed. of the 10th European Meet. of Environ. and Engin. Geophysics, Utrecht, The Netherlands, 1-4.

[30] Eppelbaum, L., Kouznetsov, S., Sazonova, L., Korotaeva, N., Smirnov, S., Vaksman, V., Klepatch, C., Surkov, A. Itkis S. and M. Smeseh, 2003. Results of integrated geologicalgeophysical examination of Makhtesh Ramon area (southern Israel) on diamond-bearing associations. Selected Papers of the SPIE Meeting, Section: Geology and Remote Sensing, Barcelona, Spain, 109-120.

[31] Eppelbaum, L.V. and Pilchin, A.N., 2006. Methodology of Curie discontinuity map development for regions with low thermal characteristics: An example from Israel. Earth and Planetary Sciences Letters, 243, Nos. 3-4, 536-551.

[32] Eppelbaum, L.V., Vaksman, V.L., Klepatch, C.A., Modin, I., Kouznetsov, S.V., Surkov, A.V., Korotaeva, N.N., Smirnov, S.A. and Bezlepkin, B.A., 2002. Discovering of diamondiferous association in the Makhtesh Ramon area, Negev desert (Southern Israel). Romanian Jour. of Mineral Deposits, 80, 25-28.

[33] Eppelbaum, L.V., Vaksman, V.L., Kouznetsov, S.V., Sazonova, L.M., Smirnov, S.A., Surkov, A.V., Bezlepkin, B., Katz Y.I., Korotaeva, N.N. and Belovitskaya G., 2006. Discovering of microdiamonds and minerals-satellites in Canyon Makhtesh Ramon (Negev desert, Israel). Doklady Earth Sciences (Springer), 2006, 407, No. 2, 202-204.

[34] Eskel, M., Kalmanovich, E. and Roup, A., 2007. The diamonds andkimberlite indicative minerals within the context of stratigraphy and source in Shefa Yamim drill SY-15, PliocenePlestocene, Qishon River Valley, Israel. Trans. of the Conf. of the Israel Geol. Soc. Ann. Meet., Dead Sea, p. 29. 
[35] Eyal, M., Becker, A. and Samoylov, V., 1996. Mt. Arod - an Early Cretaceous basanitic volcano with a fossil lava lake. Israel Jour. of Earth Sci., 45, 31-38.

[36] Flexer, A., Rosenfeld, A. and Honigstein, A., 1988a. The periodicity of possible extraterrestrial signatures in the Mesozoic-Cenozoic succession of Israel. Trans. of the Conf. of Israel Geol. Soc. Ann. Meet., En Boqeq, 27-28.

[37] Flexer, A., Rosenfeld, A., Honigstein, A. and Dvorachek, M., 1988b. A microdiamond additional support for extraterrestrial signatures near the K/T boundary in Israel. Lunar Planet. Sci., 19, p. 337.

[38] Folkman, Y. and Yuval, Z., 1976. Aeromagnetic map of Israel, 1:250,000. Israel Inst. for Petroleum Research and Geophysics, Holon, Israel.

[39] Garfunkel, Z. 1993. The Arod Pass area: structural-stratigraphic relations and their implications for the history of the Ramon lineament. Israel Jour. of Earth Sci., 42, 165-175.

[40] Garfunkel, Z. and Derin, B., 1988. Reevaluation of the latest Jurassic-Early Cretaceous history of the Negev and the role of magmatic activity. Israel Jour. of Earth Sciences, 37, 43-52.

[41] Garfunkel, Z. and Katz, A., 1967. New magmatic features in Makhtesh Ramon, southern Israel. Geological Magazine, 104, No. 6, 608-629.

[42] Giuliani, A., Kamenetsky, V.S., Kendrick, M.A., Phillips, D., Wyatt, B.A. and Maas, R., 2013. Oxide, sulphide and carbonate minerals in a mantle polymict breccia: metasomatism by protokimberlite magmas, and relationship to the kimberlite megacrystic suite. Chemical Geology, 353, 4-18

[43] Green, H. W., II and Gueguen, Y., 1974. Origin of kimberlite by diapiric upwelling in the upper mantle. Nature, 249, 617-620.

[44] Griffin, W.L., 2008. Major transformations reveal Earth's deep secrets. Geology, 36, No. 1, 9596.

[45] Griffin, W.L. and Ryan, C.G., 1995. Trace elements in indicator minerals: area selection and target evaluation in diamond exploration. Jour. of Geochemical Exploration, 53, 311-337.

[46] Gvirtzman, Z., Bartov, Y., Garfunkel, Z. and Rotstein, Y., 1994. Mesozoic magmatism in the central Negev (southern Israel): implications from magnetic anomalies. Israel Jour. of Earth Sci., 43, 21-38.

[47] Gvirtzman, G., Weissbrod, T., Baer, G. and Brenner, J., 1996. The age of Aptian stage and its magmatic events: New Ar-Ar ages and paleomagnetic data from the Negev, Israel. Cretaceous Research, 17, 293-310.

[48] Haggerty, S.E., 1995. Upper mantle mineralogy. Jour. of Geodynamics, 20, No. 4, 331-364.

[49] Ilupin, I.P., 1984. Discovering of "kimberlite" minerals in non-kimberlite igneous rocks. Trans. of TsNIGRI, No. 188, 46-51 (in Russian).

[50] Ilupin, I.P., Vaganov, V.I. and Prokopchuk, B.I., 1990. Kimberlites. Nedra, Moscow (in Russian).

[51] Issar, A., 1983. Emerging ground water, a triggering factor in the formation of the Makhteshim (erosion cirques) in the Negev and Sinai. Israel Jour. of Earth Sci., 32, Nos. 1-2, 53-61.

[52] Itamar, A., 1988. Polymetallic mineralization in Makhtesh Ramon and Har Arif, central Negev, Israel. Geological Survey of Israel, Bull. No. 18, Jerusalem, 1-56.

[53] Jall, J., 2016. Dead Sea sinkholes growing at alarming rate. The Times of Israel, http://www.timesofisrael.com/dead-sea-sinkholes-growing-at-alarming-rate (last visited 22.01.2017)

[54] Kaminsky, F.V., Feldman, A.A., Varlamov, V.A., Boyko, A.N., Olofinsky, L.N. Shofman, I.L. and Vaganov, V.I., 1995. Prognostication of Primary diamond deposits. Journal of Geochemical Exploration, 53, 167-182.

[55] Kaminsky, F.V. Frantenson, Ye.V. and Khvostova, V.P., 1974. First information on platinum metals (Pt, Pd, Rh, Ir, Ru, Os) in kimberlitic rocks. Dokl. Acad. Sci. USSR, Earth Sci. Sect., 219, 190-193.

[56] Katz, Y.I. and Eppelbaum, L.V., 1998. Larson's Mid-Cretaceous Superplume Effect and a new look to Israeli territory as perspective to kimberlite pipes discovering. Trans. of the Ann. Meet. of the American Geol. Soc., Toronto, Canada, Section: Planetary Geology, 30, No. 7, p. A289. 
[57] Kharkiv, A.D., Zinchuk, N.N. and Kruchkov, A.I., 1995. Geological-Genetical Foundations of Schlich-Mineralogical Method of Searching Diamond Deposits. Nedra Publ., Moscow (in Russian).

[58] Kharkiv, A.D., Zinchuk, N.N. and Zuev, V.M., 1997. The History of Diamond. Nedra. Moscow (in Russian).

[59] Koralov, L. and Sinai, Y.G., 2007. Theory of Probability and Random Processes, $2^{\text {nd }}$ Ed. Springer, Berlin-Heidelberg.

[60] Kutinov, Yu.G. and Chistova, Z.B., 2016. Arkhangelsk diamondiferous province on small-scale geological, tectonic and geophysical maps. Space and Time, 11, No. 1

[61] Lang, B., Hebeda, E.H., Preim, H.N.A., Steinitz, G. and Veradurmen, E.A.Th., 1988. K-Ar and $\mathrm{Rb}-\mathrm{Sr}$ ages of Early Cretaceous magmatic rocks from Makhtesh Ramon, southern Israel. Israel Jour. of Earth Sci., 37, 65-72.

[62] Lang, B. and Steinitz, G., 1985. New K-Ar ages of Early Cretaceous rocks from Makhtesh Ramon, southern Israel. Trans of the Ann. Meet. of Isr. Geol. Soc., 52-56.

[63] Lang, B. and Steinitz, G., 1989. K-Ar dating of Mesozoic magmatic rocks in Israel: A review. Israel Jour. of Earth Sci., 38, 89-103.

[64] Larson, R.L., 1995. The Mid-Cretaceous superplume episode. Scientific American, 282, No.2, 82-86.

[65] Lavi, N., Lipshitz, G., Neeman, E., Itamar, A. and Baer, G., 1988. Determination of trace amounts of gold in the presence of rare earth elements in rock samples from Makhtesh Ramon (Southern Israel), by instrumental epithermal neutron activation analysis. Journal of Radioanalytical and Nuclear Chemistry, 120, No. 1, 105-112.

[66] Le Roex, A.P., Bell, D.R. and Davis, P., 2003. Petrogenesis of group I kimberlites from Kimberley, South Africa: Evidence from bulk-rock geochemistry. Journal of Petrology, 44, No. 12, 2261-2286.

[67] Marshall, T.R. and Baxter-Brown, R., 1995. Basic principles of alluvial diamond exploration. Jour of Geochemical Exploration, 53, 277-292.

[68] McClenaghan, M.B., Thorleifson, L.H. and DiLabio, R.N.W., 2000. Till geochemical and indicator mineral methods in mineral exploration. Ore Geology Reviews, 16, 145-166.

[69] Mahfoud, R.F., 2002. Presence of diamond in the pyrope peridotite, Dreikeesh area, Tartous province, NW Syria: a new theory on the origin of diamond. Microchemical Journal, 73, No. 3, 265-271.

[70] Milashev, V.A., 1974. Kimberlite Provinces. Nedra, Leningrad (in Russian).

[71] Mitchell, R.H., 1986. Kimberlites - Mineralogy, Geochemistry and Petrology. Plenum, N. Y.

[72] Mitchell, R.H., 1995. Kimberlites, Orangites, and Related Rocks. Plenum Press, New York.

[73] Morgan, P., 1995. Diamond exploration from the bottom up: regional geophysical signatures of lithosphere conditions favorable for diamond exploration. Jour. of Geochemical Exploration, 53, 145-165.

[74] Mukhin, P., Eppelbaum, L., Wirth, R., Schreiber, A. and Dobrzhinetskaya, L., 2015. First find of $4 \mathrm{H} \mathrm{SiC} \mathrm{polytype} \mathrm{in} \mathrm{situ} \mathrm{in} \mathrm{volcanic} \mathrm{rocks} \mathrm{of} \mathrm{northern} \mathrm{Israel} \mathrm{(Invited} \mathrm{Lecture).} \mathrm{Trans.} \mathrm{of} \mathrm{the}$ Goldschmidt Conf., (European Assoc. of Geochemistry and the Geochemical Society), Prague, Vol. 25.

[75] Nixon, P.H., 1995. The morphology and nature of primary diamondiferous occurrences. Jour. of Geochemical Exploration., 53, 41-71.

[76] Nowak, P., 2010. Influence of surfactant adsorption on the leaching of copper sulfides. ECS Transactions, 28, No. 6, 143-153.

[77] Rosenfeld, A., Flexer, A., Honigstein, A., Almogi-Labin, A. and Dvorachek, M., 1989. First report on a Cretaceous/Tertiary boundary section at Makhtesh Gadol, southern Israel. N.c.b. Geol. Palaont. Mh., Stuttgart, 474-488.

[78] Rybakov, M. and Segev, A., 2004. Top of the crystalline basement in the Levant. Geochemistry, Geophysics, Geosystems, 5, Q09001, 1-8, doi: 10.1029/2004GC000690. 
[79] Samoilov, V.S. and Vapnik, E., 2007. Fractional melting - the determining factor in the origin of the tephtite - basanite - nephelinite rock suite: evidence from western Makhtesh Ramon, Israel. N. Jb. Miner. Abh., 184/2, 181-195.

[80] Samykina, E., Surkov, A., Eppelbaum, L. and Semenov, S., 2005. Do old spoils contain large amounts of economic minerals? Minerals Engineering, 18, No. 6, 643-645.

[81] Shcheka, S.A., Ignat'ev, A.V., Nechaev, V.P. and Zvereva, V.P., 2006. First diamonds from placers in Primor'e. Petrology (Springer), 14, No. 3, 299-317.

[82] Segev, A., 2000. Synchronous magmatic cycles during the fragmentation of Gondwana: Radiometric ages from the Levant and other provinces. Tectonophysics, 325 (3-4), 257-277.

[83] Segev, A., Weissbrod, T. and Lang, B., 2005. ${ }^{40} \mathrm{Ar} /{ }^{39} \mathrm{Ar}$ dating of the Aptian-Albian igneous rocks in Makhtesh Ramon (Negev, Israel) and its stratigraphic implications. Cretaceous Research, 26, 633-656.

[84] Sharygin, V.V., Kóthay, K., Szabó, Cs., Timina, T.Ju., Török, K., Vapnik, Ye. and Kuzmin, D.V., 2011. Rhönite in alkali basalts: silicate melt inclusions in olivine phenocrysts. Russian Geology and Geophysics, 52, 1334-1352.

[85] Sneh, A., Bartov, Y. and Rozensaft, M., 1998. Geological Map of Israel, Scale 1:200,000. Geol. Survey of Israel, Min. of Nation. Infrastructure, Jerusalem.

[86] Shimshilashvili, E. and Yudalevich, Z., 2005. Mechanism of phenocryst formation in alkaline ultrabasic and basic volcanic rocks: Evidence from Makhtesh Ramon, southern Israel. Israel Jour. of Earth Sci., 54, 113-120.

[87] Sobolev, N.V., 2006. Coesite as an indicator of ultrahigh pressures in continental litosphere. Russian Geology and Geophysics, 47, No. 1, 94-104.

[88] Starinsky, A., Beilsky, M. and Steinitz, G., 1980. Rb-Sr whole rock ages of syenitic intrusion Shen Ramon and Gevanim in Ramon area, southern Israel. Israel Jour. of Earth Sci., 29, 177181.

[89] Stein, M., Garfunkel, Z. and Jagoutz, E., 1993. Chronothermometry of peridotitic and pyroxenitic xenoliths: Implications for the thermal evolution of the Arabian lithosphere. Geochimica et Cosmochimica Acta, 57, 1325-1337.

[90] Surkov, A.V., 2000. Atlas of Forms of Native Gold (Sketching and Measurements by Microscope Investigations). Volumes I and II. StudiA Publ., Moscow.

[91] Surkov, A., Samykina, E., Eppelbaum, L. and Semenov, S., 2008. The Main Reason for Mineral Loss in Gravity Dressing. The Open Mineral Processing Journal, No.1, 37-44.

[92] Vapnik, E., 2005. Melt and fluid inclusions and mineral thermobarometry of mantle xenoliths in Makhtesh Ramon, Israel. Israel Jour. of Earth Sci., 54, 15-28.

[93] Zak, I., 1968. Geological Map of Israel (1:20,000). Makhtesh Ramon, Har Gevanim. Israel Geol. Survey.

[94] Zilberman, E., 1991. Landscape evolution in the central, northern and northwestern Negev during the Neogene and the Quaternary. Isr. Geol. Surv. Rep. GSI/45/90, 164 pp. (in Hebrew, English abstract).

[95] Zilberman, E., 2000. Formation of "makhteshim" - unique erosion cirques in the Negev, southern Israel. Israel Jour. of Earth Sci., 49, 127-141. 


\section{AUTHORS' BIOGRAPHY}

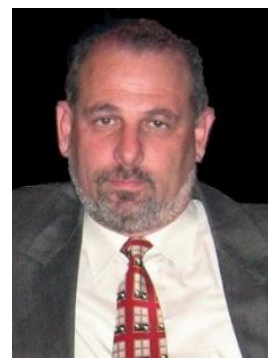

Lev V. Eppelbaum, was born in Tbilisi (Georgia) on 18.05.1959. He received M.Sc. in 1982 from the Azerbaijan Oil \&Gas Academy, and PhD in 1989 from the Geoph. Inst. of the Georgian Acad. Sci. and Moscow Mining Acad. During 19911992 he had Postdoctoral Studies at the Department of Geophysics, Tel Aviv University (TAU). From 1991 to 2005 he occupied positions of Researcher, Senior Researcher and Senior Lecturer at Dept. of Geophysics (TAU); in 2005 he received at this Dept. a position of Principal Research Associate (Associated Professor). His main research interests include applied and environmental geophysics, tectonics and geodynamics. He is author of about 350 publications including 9 books and more than 130 articles. The most significant books are 'Interpretation of Geophysical Fields in Complicated Environments' (Kluwer Acad. Publ., 1996), 'Geophysical Studies in the Caucasus' (Springer, 2012), 'Applied Geothermics' (Springer, 2014) and 'Geophysical Potential Fields: Geological and Environmental Applications' (Elsevier, 2017). From 1982 to 1990 he worked as a Researcher and Senior Researcher at the Institute of Geophysics in Baku (Southern Branch of the AllUnion Geophysical Prospecting Institute). Prof. Lev Eppelbaum is member of Society of Exploration Geophysicists, EuroScience, American Geophysical Union, European Association of Exploration Geophysicists, International Society for Archaeological Prospection, International Association for Promoting Geoethics, EARSeL SIG (remote sensing and archaeology), Society of Mediterranean Geologists and Geophysicists, Israel Geological Society and Prehistoric Society of Israel. He is Assoc. Editor in the "Geophysical Instrumentation, Methods and Data System" and "International Journal of Materials, Methods \& Technologies", member of Editorial Board of the "Archaeological Discovery", "Positioning", "International Jour. of Earthquake Engineering", "Open Mineralogical Processing Journal", "Open Petroleum Engineering Journal", "LatinMag Letters", "Stratigraphy and Sedimentology of Oil \& Gas Basins", "Izvestiya Azerbaijan Acad. Sci.", "International Journal of Mining Sciences", and Guest Editor of "Advances in Geosciences", "Jour. of Geophysics and Engineering" and "Near-Surface Geophysics". Lev is a member of the International Commission 'Rotation of the Earth' and member of the WebmedCentral Ecology Advisory Board. In January 2017 Lev. Eppelbaum was elected as Foreign Member of the Russian Academy of Natural Sciences. Google Scholar gives 3,235 citations to his publications, and his $R G$ Score is $\mathbf{4 0 . 3 8}$ (January 23, 2017).

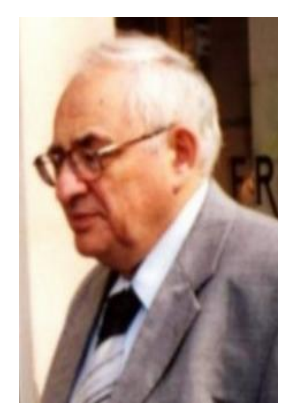

Vladimir L. Vaksman, was born in Moscow (Russia, USSR). He received M.Sc. (1958) and $\mathrm{PhD}$ (1969) from the Moscow Exploration Inst. Vladimir Vaksman occupied positions of Design Engineer (1959-1962, Ministry of Geology of the USSR), Drilling Engineer (1962-1966, All-Union Assoc. of Drilling Projects, USSR), Senior Researcher and Head of Drilling Laboratory (1976-1987, Inst. of Geological Exploration, Moscow, USSR). After immigration to Israel he occupied position of a Leading Engineer in the Mekorot Water Co. (1987-1996). His main research interests include drilling of boreholes in complex environments. $\mathrm{He}$ is author of about 50 publications and 3 patents. Dr. Vaksman received in 1971 a Silver Medal of the Industrial Water Assoc. of the USSR. Since 1997 he is a President of the 'KVGRS Geological and Environmental Company' (Tel Aviv, Israel). 